\title{
Directive 85/374 - European Victory or a Defective Product Itself?
}

\author{
Martin Ueffing
}

\section{Introduction}

Over the last few decades, product liability has become a well-established area of European private law. It surfaced as a subject in its own right in the US in 1963 in the judgment of Greenman v Yuba Power Products.' In contrast, modern European product liability originated over two decades later when Directive 85/374 was introduced in 1985 , concerning liability for defective products (Product Liability Directive hereafter), and embracing the idea of strict liability of manufacturers for damage caused by circulating a defective product. The Directive aims for full harmonisation and the provision of a high and equal level of consumer protection. In recent years the EU Product Liability Directive has become something of a global smash hit, providing not only a template for EU Member States, but also an international blueprint used by countries worldwide, including South Africa, Australia, Brazil and countries in the Asia Pacific Region when reforming their product liability regimes. ${ }^{2}$

There is no doubt that the Directive politically speaking has been a major success, representing arguably the most powerful example of European harmonisation efforts within the area of tort law where previous initiatives have failed, ${ }^{3}$ and influencing the law worldwide. However its actual impact has been negligible; The Directive has not done much to unify EU product liability law in action, nor strengthened consumer protection. In the majority of countries the implementation of the Directive has not significantly affected the nature or frequency of product liability litigation. If victims sue at all they rarely make use of the special legislation implementing the Directive's strict liability rules.

The question that will be dealt with in this paper is twofold; firstly has the legal framework imposed by Directive 85/374 led to "complete" harmonisation of product

\footnotetext{
1 Greenman v Yuba Power Products 337 p.2d 897 (Cal.1963). Announced that from thereon manufacturers of defective products would be strictly liable in tort to the ultimate consumer.

2 Reimann 2003, p.134.

3 Faure 2000, p.467.
} 
liability laws within Europe? (Section 2), And second, if it is not complete, is further harmonisation within this sector of private law feasible? (Section 3). In accordance with the recent case law of the ECJ the Directive has a "maximal harmonisation' nature, which precludes Member States from adopting more stringent provisions. Nonetheless this paper argues that the Directive has not led to complete harmonisation of product liability and highlights several obstacles to a fully harmonized product liability regime. In particular the Directive in fact is not one rule but merely, in accordance with Article 13, has added onto existing regimes another layer of dissimilar rules. The rules imposed vary in accordance with optional provisions that allow Member states to derogate from the instrument, which, in conjunction with several matters left to be determined by national law such as issues of causation, means that the Directive by no means is self-standing, but is heavily dependent on national law. The Directive thereby coexists with previously offered, and often more favorable, methods of recovery, providing consumers with a choice. This paper hereby argues that the main problem lies within the Directive's ambiguous phraseology and specifically its lack of guidance concerning key constitutive elements that make up a cause of action. Next this paper addresses whether further harmonisation within this sector of private law is feasible (Section 3). What can we learn from the product liability experience so far as to the need and degree of harmonisation required by the internal market? Moreover, is harmonizing product liability laws an exclusive task of the European institutions, or one requiring the cooperation between the national and supranational levels? Lastly, this paper will draw conclusions from earlier sections and provide an outlook regarding the future of European product liability law as well as harmonisation within the field of private law in general (Section 4).

\section{The quest for a "unified system" of liability for defective products}

Liability for loss caused by defective products had long been within the preserve of the national legislator, and plaintiffs had to rely on traditional theories of tort and contract law. During the 1970's several European organizations embarked on developing proposals that would coordinate European, and also international, product liability laws. The first initiative arose in 1974 from the Committee on Legal Corporations (CCJ hereafter) of the Council of Europe, which proposed a Convention on Product Liability (the Strasbourg 
Convention) imposing strict liability on manufacturers in personal injury and death cases. ${ }^{4}$ This was followed shortly thereafter by a Convention addressing the conflicts of laws in product liability cases in $1977 . .^{5}$

Prior to $27^{\text {th }}$ July 1985 Member states' positions concerning liability for defective products differed, ranging from traditional fault-based liability in the UK, to fault liability with a reversed burden of proof in Germany, and strict and unlimited liability with an irrebutable presumption of fault in e.g. France. ${ }^{6}$ The Commission argued that different liability rules and safety standards, would unevenly increase production costs in various Member states as well as impose different marketing conditions, and therefore inevitably restrict the free movement of goods and distort the internal market. ${ }^{7}$ The Commission therefore sought to approximate the existing laws on the basis of Article $100 \mathrm{EEC}^{8}$ (now Article 115 TFEU).

The process of "Europeanization" within the area of product liability has therefore been a planned transition rather than the result of bottom-up pressure ${ }^{9}$, spurred by internal market as well as political and social concerns. Undoubtedly the thalidomide disaster in the 1960's had been an important historical trigger, captivating European attention on cases concerning unforeseeable generic product defects..$^{10}$ It was however the German reaction towards this pharmaceutical liability crises that most likely gave the EU the last push: while most Member states referred to private sectoral initiatives, Germany decided to pass a statute imposing strict liability for injuries caused by defective pharmaceutical drugs."

4 European Convention on Product Liability in Regard to Personal Injury and Death, T.S. No.91, Strasbourg 27 January 1977. Based on the initial report composed by the Committee of Experts on Liability of producers and the UNIDROIT.

5 Hague Convention on the Law Applicable to Production Liability. October 21 $1^{\text {st }}$, 1972. I.L.M.1283.

6 Report of the Legal Affairs Committee [1979-1980] European Parliament Document COM No.71 p.12. See also: Thieffry 1989, p.65-67.

7 Faure 2000, p.469.

8 Art.115 TFEU provides that the Council, acting unanimously and after consulting the European Parliament and the Economic and Social Committee, may issue Directives for the approximation of laws, regulations and administrative provisions of Member State where divergence between them significantly affects the establishment or functioning of the internal market.

9 Bernstein 1992, p.208.

10 Science in Society. Thalidomide was prescribed during 1957 and 1962 to expectant mothers to treat morning sickness, anxiety and insomnia. However it was withdrawn from the market after more than 10.000 babies, exposed to thalidomide while in the womb of their mother, were born with severe birth defects.

11 German Medicinal Act (Arzneimittelgesetz) 16 May 1961 Federal Gazette I S. 533, as amended by 16 December 2005 Federal Law Gazette I S. 3394. Crucial provisions in the German law are equivalent to those proposed by Directive $85 / 374 /$ EEC. 
A preliminary draft Directive was presented in August 1974 then modified in $1975^{12}$ and officially proposed on September 9, 1976, followed by another amendment in $1979 .{ }^{13}$ In accordance with Article 115 the Commission submitted the proposal to the European Parliament and ECOSOC, where it met with harsh criticism as being too pro-consumer by imposing strict liability whenever a product fails to provide the safety a person is entitled to expect. ${ }^{14}$ The Parliament, as well as ECOSOC, claimed that any future Directive had to provide for exculpatory provisions in favor of the defendant. Their main concern was that the industry should not be liable for defects of products that could not have been manufactured to a safer standard at the time they were circulated. ${ }^{15}$ Both the European Parliament as well as the Council, although acknowledging the need for harmonisation, urged for the inclusion of a development risk defense that would limit producers' liability to defects which are foreseeable based on the scientific knowledge available at the time the product is introduced to the market, which would provide substantial protection especially to new and innovative firms. ECOSOC's position ${ }^{16}$ was torn as some members felt that including a development risk defense would seriously inhibit innovation and place, especially, small or medium sized companies and industries in a less competitive position. This would be due to increased transaction costs created by the need to insure themselves against unforeseeable risks. Moreover the European Parliament emphasized that the defendant should be able to allege contributory negligence. ${ }^{77}$ More generally, ECOSOC voiced concern about the Directive relating to its treatment of financial ceilings, opposing any form of limitation that may leave victims of major disasters unprotected. ${ }^{18}$

12 Linger 1991, p.479

Proposal for a Council Directive Relating to the Approximation of the Laws, Regulations and Administrative Provisions of the Member States Concerning Liability for Defective Products. O.J. C 241/9 (1976) as amended by Council Directive relating to the Approximation of Laws, Regulations and Administrative provisions of the Member States concerning liability for defective products. O.J. C271/3 (1979).

European Council; Council Resolution embodying the Opinion of the European Parliament on the Proposal from the Commission of the European Communities to the Council for a Directive relating to the Approximation of the laws, Regulations and Administrative provisions of the Member States Concerning Liability for Defective Products Article 4. OJ C127/61 (1979). Economic and Social Committee (ECOSOC) 1976, p.41-5. Economic and Social Committee 1979.

17 European Council; Council Resolution embodying the Opinion of the European Parliament on the Proposal from the Commission of the European Communities to the Council for a Directive relating to the Approximation of the laws, Regulations and Administrative provisions of the Member States Concerning Liability for Defective Products Article 5. OJ C127/61 (1979). 
According to some authors the product liability crisis experienced by the US during the $1980^{\prime} s^{19}$ and the accompanying debate concerning the impact of product liability rules on market productivity conditioned the drafting of a EU product liability Directive. ${ }^{20}$ As a consequence the Community, but especially the business sector, led by the Union of Industrial and Employers Confederations of Europe (UNICE hereafter), feared that introducing a strict liability standard would result in absurd insurance rates and a dramatic increase in liability claims and lawsuits, which had been the case in the US. ${ }^{21}$

The Commission, however, remained sceptical towards pro-defendant amendments, insisting on the implementation of a no-fault liability approach. During the 1970's Europe saw the rise of the "Consumerism:" political agenda followed by the Commission namely to give Europe a human face. The promotion of equal consumer protection across the Community became an important goal, through which the Commission sought to demonstrate that the common market was not only there to facilitate trade and serve businesses but also to aid consumers. ${ }^{22}$

The Commission firmly believed that existing consumer protection rules were inadequate, as they hindered victims of product-related injury in recovering compensation, for example by requiring plaintiffs to prove negligence on the part of a manufacturer, which was extremely difficult due to their lack of technical expertise, while it was relatively easy for businesses to rebut any accusations of negligence. ${ }^{23}$ Therefore, the Commission defended the view that the producer should be liable to organize and supervise, in order to minimize risk of damage or injury, which it justified by arguing that the producer has easiest access to information and evidence to determine whether a product is defective and is therefore well placed to prevent harm and to insure or spread the cost of risk. Moreover, the Commission pointed towards recent national case law, which showed a genuine willingness to create a strict liability standard for defective products. ${ }^{24}$ Additionally the great emphasis on

19 Allee 1984, p.1-13. During this period there was a dramatic increase in number of product liability cases, size of recoveries and cost of insurance and loss prevention programs as well as inconsistent obligation and liability standards among the various states.

Cavaliere 2001, p.4.

Orban 1978, p.374. During the 1950's not much emphasis was placed on consumer protection as EU legislators believed that there interest were indirectly served by e.g. increasing the free movement of goods or services.

23 European Commission 1976, p.2.

24 Hof Amsterdam 27 June 1957, NJ 1958, 104 Ford v Den Ouden; as well as opinion of Judge Traynor in Escola v Coca-Cola Bottling Co. 24 Cal. 2d 453, at 462, 440-441 [1994]. 
consumer protection may be explained simply by the fact that in a developing industrial economy the increasing demand for safety is linked to growing incomes. ${ }^{25}$

Through the 1980's, finalization of the proposed Directive seemed doubtful, as earlier dialogue and debate had not reached a resolution by late 1984, due to the fact that many national governments demanded amendments in order to preserve their sovereignty. The UK, for example, made its approval subject to the inclusion of a state of the art defense, using its veto to ensure the protection of the producer who did everything to ensure the safety of his product. ${ }^{26}$ Several authors therefore argue that the final result became a "high water mark of political Euro-fudge" that tried to square the circle of disagreement among Member states by using ambiguous terms. ${ }^{27}$ The array of options left to Member states reflects the extent to which the Commission had to compromise; thus the final version provides that any Member State may choose whether to provide or maintain a state of the art defense, as well as a limit on producers' total liability to an amount not less than 70 million ECU. ${ }^{28}$

\subsection{The Product Liability Directive}

Directive $85 / 374 /$ ECC $^{29}$, creating a regime of liability for defective products, was adopted and notified to the Member States in 1985 , nine years after its original proposal in $1976.3^{\circ}$ Member states were obliged to bring implementing national legislation into force no later than July $27,1988 .{ }^{31}$ However, by 1990 only seven states had implemented the Directive, of which only four complied with the deadline. ${ }^{32}$

The Directive aims at creating a common basis for liability of producers in relation to

25 Cavaliere 2001. p.4.

26 Stapleton 2002, p.1247-1249.

$27 \mathrm{lbid}$. Even the ECJ criticized the Directive as hard to interpret see its judgment in C-300/95 Commission v United Kingdom [1997] ECR I-2649, 1997 ALL ER 481.

28 Art. 15 and 16 Directive 85/374. See also: Nilles 1985, p.751-752. On the development risk defense the Commission compromised: it rejected the version proposed by the European Parliament that may lead to a complete bar to liability which the Commission feared would possibly unduly burden the consumer to bear the risk of the unknown. Council Directive 85/374/EEC O.J. No. L141/20 of 4.6.1999.

30 Commission of the European Communities; Proposal for a Council Directive relating to the approximation of laws, regulations and administrative provisions of the Member States concerning liability for defective products. (O.J C. 241/9 Oct. 14, 1976).

31 Art.19 Directive 85/374.

32 Mottur 1994, p.993. These Member States were Denmark; UK; Germany; Greece; Italy; Luxembourg; Portugal. 
damage resulting from defectiveness of their products in an area notorious for diverse approaches across member states. 33

A common standard of strict liability is introduced, a concept previously unknown to Member states, where negligence on the part of the producer was the rule. Consequently, any producer of a movable is liable to compensate for damage caused by a defect in his product. ${ }^{34}$ It was thought that only liability without fault could adequately resolve the problem of fair apportionment of risks that are inherent in modern technological production. ${ }^{35}$ Moreover, the Directive sought to relieve consumers from the burden of proving negligence or the overly technical requirements of warranty. ${ }^{36}$ To this end the Directive restricts the producers' freedom of contract, rejecting any limitation or exemption from potential liability through contractual derogations. 37

\subsubsection{The Defendant}

The definition of "producer" adopted by the Directive is comprehensive, encompassing manufacturers of a finished product, producers of raw material ${ }^{38}$ or a component part; with any person that by putting name, trademark or other distinguishing feature on the product presents himself as the producer also referred to as "quasi-producer". ${ }^{39}$ Consumers prefer to sue the manufacturer of a finished good as they often lack the expertise to trace a possible defect in one of the component parts. ${ }^{\circ \circ}$ Consequently, under the Directive, strict liability of the manufacturer of a component part does not exempt the producer of the finished product from liability. The latter will be liable for damage caused by a defect in connection with the finishing of the good, as well as defects in any component part of

33 See Recital 1 and 5 Preamble Directive 85/374.

34 Art.1 Directive 85/374. Directive does not refer to "strict liability" or "strict product liability" but refers to liability without fault on part of the producer.

35 Recital 2 Preamble Directive 85/374.

36 Korzec 1997, p.230.

37 Art.12 Directive 85/374.

38 Korzec 1997, p.141. "Raw material" is raw products and materials used in the production of either semi or finished products e.g. coal, chemicals, minerals, and sand.

39 Art.3 (1) Directive 85/374. "Finished good" hereby refers to the way the product appears in the hands of the consumer when there is no need for further alteration or addition in order to provide the good in accordance with its "intended use". Moreover so called "quasi producers" refer to e.g. department stores and commercial chains when they sell the products in their own name without referring to their actual origin. Hulsenbek \& Campbell 1989, p.20. 
the product. ${ }^{41}$ Additionally, "putting one's name, trademark or distinguishing feature" on a product is interpreted broadly; It is not required that the trademark is placed on the product itself for example. Consequently, the Directive provides for joint and several liabilities ${ }^{42}$, so that consumers should be able to claim full compensation from anyone of the manufacturers of the finished good or its component parts. ${ }^{43}$ Although fully liable, the party that indemnifies the injured consumer has a right to contribution claims against the others in proportion to the risk attributable to them. ${ }^{44}$ Furthermore, any person importing into the Community a product for sale, hire, leasing or other form of distribution in the course of his business will be deemed a producer and therefore liable for defects. ${ }^{45}$

The intent of the importer becomes crucial within this context, since it will determine whether he qualifies as producer. One may distinguish between the situation where the product is originally imported in the course of business but later used for personal use, and the reverse. While in the former case the importer will not be relieved from qualifying as a producer under the Directive, in the latter case subsequent commercial use of the product will not qualify him as a producer. The provision relates to importers that import into and not within the community. By allowing consumers to sue importers, the Directive sought to spare consumers unnecessary lawsuits against producers established outside the EU common market. This provision coincides with the approach followed by the EC Regulation 44/2001 (Brussels I hereafter), ${ }^{46}$ wherein Article 5 (3) stipulates that product liability suits may be brought "at the place where the harmful event occurred", in most cases where the injured party has his/her domicile.

The Directive provides vicarious liability for the situation where the injured party is not reasonably able to identify the manufacturer; in which case the supplier of the product will be treated as the producer ${ }^{47}$ unless he informs the injured party within a reasonable timeframe of the identity of either the producer or his supplier, and provided that such person can be

\footnotetext{
41 Folsom et al. 1996, p.140.

42 Art.5 Directive 85/374.

43 Recital 5 Preamble Directive 85/374.

44 Art.5 Directive $85 / 374$. However this provision applies without prejudice to provisions of national law concerning the rights of contribution and recourse. See also: Hunter et al. 2001, p.404.

45 Art.3 (2) Directive 85/374.

46 Council Regulation No 44/2001 O.J. L 012, 16.01.2001, p.1-23. Note also important Art.31 of the Regulation provides that a judgment from one Member State may be enforced in another where the importer has his place of business.

47 See also: CJEU judgment in C-358/08 Aventis Pasteur SA v OB [2009] ECR I-11305.
} 
held liable..$^{8}$ The same applies in case of products imported from third countries where their origin cannot be identified.Justification s for not being able to ascertain the producer's identity will not exclude the supplier's liability. However, retailers are generally excluded from the scope of the Directive, notwithstanding situations in which they are regarded as producers. ${ }^{49}$ Neither does the scope extend to service providers, however referring to the ECJ judgment in Centre hospitalier universitaire de Besançon ${ }^{50}$ the Directive does not preclude national law from holding persons liable for using defective products while providing services, such as in the case public health care providers..$^{51}$

\subsubsection{The Object}

The definition of "product" has been extended to cover all movables, even when temporarily or permanently incorporated into another movable or immovable, including electricity..$^{52}$ Courts throughout the different jurisdictions have considered blood supplied by blood banks, for example, to fall within the definition..$^{53}$ Important to note here is that the Directive only covers products which have been put into circulation ${ }^{54}$ after the Directive has been implemented in the respective national system. ${ }^{55}$ The Directive was amended in

48 Art.3 (3) Directive 85/374. See also: the judgment in Case C-402/03 Skov v Bilka Lavrishareus [2006] ECR I-199 where the court held that Art.3 (3) must be interpreted as being exhaustive, precluding national law under which the supplier is answerable for a defective product other than those listed.

49 Folsom et al. 1996, p.142. The main reason behind this policy choice may be traced back to the fact that Member States differ considerably in their regulation of product liability for retailers e.g. Denmark introduced strict liability for retailers that differentiates to the one applicable to producers.

50 C-495/10 Centre hospitalier universitaire de Besançon v Thomas Dutrueux [2011] ECR I-ooooo. According to Advocate General Mengozzi the scope does not extend to service provides as the scope is restricted to manufacturers liability and extended to other parties in the distribution chain, however it does not govern all aspects of liability for defective products leaving topics untouched open for regulation by the member states.

51 Folsom et al. 1996, p.140.

52 Art.2 Directive 85/374.Goods don't need to be consumer goods nor goods that are primarily designated for private consumption.

53 A v National Blood Authority [2001] 3 All ER 289, nr.63; Rb. Amsterdam 3 February 1999, NJ 1999, 621 (Scholten v Sanquin Bloedvoorziening).

54 C-127/04 Declan O'Byrne v Sanofi Pasteur MSD Ltd. [2006] 2 CMLR 24 para.25'...To be interpreted as meaning that a product is put into circulation when it is taken out of the manufacturing process operated by the producer and enters the marketing process in the from in which it is offered to the public in order to be used or consumed.'

Art.17 Directive 85/374. Therefore referring to Art.19 the 27 July 1998. 
$1999^{56}$, as a result of measures taken by the EU to fight against the BSE crisis 57 , expanding its scope to include agricultural products, which until then had been exempted. It was thought that inclusion of agricultural products within the scope would restore consumer confidence in the safety of such products by facilitating legitimate compensation for damage to the benefit of the consumer. Previously, Member states could, by way of derogation, decide whether to include primary agricultural products and game within the term "product," 58 leading to different outcomes and undermining the goal of a common standard.

\subsubsection{Determination of "defect"}

In establishing the existence of a defect focus is placed on the condition of the product, disregarding the conduct of the manufacturer. A consumer may only recover damages in relation to a defect in a product or a lack of the anticipated level of safety, not the product's hazardous nature or its inability to achieve some level of expected performance. ${ }^{59}$ For the legal determination of a defect, the Directive refers to the so-called consumer expectation test namely "a product is defective when it does not provide the safety that a person is entitled to expect taking all circumstances into account". ${ }^{60}$ The test makes no distinction between defects in production, design defects and a lack of warning or instructions provided to the consumer. ${ }^{61}$ The Directive mentions three considerations; (1) the presentation of the product, e.g., information concerning the product provided through media or instructions of use, whereby it will become important that potential users become aware of functional characteristics but also its operational limitations ${ }^{62}$; (2) the use to which the product can reasonably be expected to be put, whereby the manufacturer must anticipate that the consumer might use it in a negligent way by either designing product in a safer way or efficiently warning the consumer against unsafe uses; and (3) the time when the product was put into circulation, whereby defectiveness will be determined in accordance with the safety rules applicable at that particular time. ${ }^{63}$

56 Directive 1999/34/EC O.J. L. 141/20 1999.

57 Van Dam 2006, p.373.

58 Art.15 (1) (a) Directive 85/374.

59 Recital 6 Preamble Directive 85/374.

60 Art.6 Directive 85/374.

61 Hunter et al. 2001, p.404. However a distinction usually is made in practice. Hereby design and instruction defects are inherent in the product itself and therefore occur in all products of that specific type in the product whereas manufacturing defects are not inherent and only one individual product does falls short in meeting the standard of general quality of that specific type of good.

62 Van Wees \& Brookhuis 2005, p.360.Manufacturers have to maintain a balance between spelling out limitations and potential dangers even when doing so would negatively affect sales.

63 Art.6 (1) Directive 85/374. It is generally accepted that these listed circumstances are not of a limitative character. 
The test is an objective one judged by the legitimate expectations of purchasers of a particular product generally. Individual expectations are irrelevant, except to the extent that they reflect more general public expectations. The test is also normative rather than factual, as the general public is entitled to expect the safety the product ought to have, even when aware of the risk of defect. ${ }^{64}$ Adherence to mandatory regulations issued by public authorities that ascribe safety requirements will be of importance when verifying defectiveness. ${ }^{65}$ The Directive expressly provides that the subsequent existence of a better product does not per se lead to defectiveness of the product in question. ${ }^{66}$ There is no strict liability imposed for defective advice, however, one may assume that inaccurate instructions may well establish the product's defectiveness and therefore raise liability issues under the Directive. ${ }^{67}$ Several Member states also take the position that the producer should only be required to communicate reasonably foreseeable risks. ${ }^{68}$

\subsubsection{Exculpatory circumstances}

According to the aim of fair apportionment of risks, the producer should be able to exculpate himself from liability if he proves exonerating circumstances in accordance with the Directive. ${ }^{69}$ The producer has to prove that (a) he either has not given his consent to put the product into circulation, but it reached the market through force majeure or the act of a third party, or that the defect did not exist or was undetectable when the product was put into circulation by him ${ }^{70}$; (b) that the defect was caused by compliance with "mandatory" regulations issued by a public authority in the country where the product has been circulated ${ }^{71}$; (c) that the product has been made for private purposes and not to

64 Van Dam 2006, p.380.

65 Folsom et al. 1996, p.143. More frequently possible to ascribe certain expected safety requirements to the functional purpose of the product.

66 Art.6 (2) Directive 85/374.

67 Bianco 2002, p.116.

68 Civ. 1re 8 April 1999, JCP 1999. II. 20721.

69 Art.7 and 8 Directive 85/374.

70 Art.7 (a) (b) Directive 85/374. Producer not liable for any defects caused by improper handling during distribution nor for damage caused due to improper use of the product by injured party see Art. 6 (b) and (c) Directive 85/374. Subsection (b) has been regarded as superfluous in several national laws e.g. UK, France and Germany.

71 Art.7 (d) Directive 85/374. Adherence and compliance with privately agreed regulation or standards is not sufficient to discharge producer, compliance must be the actual cause of the defect. 
be sold, hired, distributed or manufactured in the manufacturers course of business ${ }^{72}$; or (d), in case of a manufacturer of a component part, that the defect can be traced back to instructions, design and standards provided for by the producer of the finished product.73

While the original proposal for the Directive excluded the so-called development risk defense, it proved impossible to find an agreement on the subject. Therefore as a compromise, it remains open for Member states to retain or provide for such defenses in their national law. ${ }^{74}$ The manufacturer accordingly will be exempt from liability where defects existing at the time the product is put into circulation could not have been discovered due to the state of science and technology at that time..$^{75}$ According to the Commission, the producer needs to be able to prove that it was absolutely impossible for anyone to discover the defectiveness. ${ }^{76}$ The Directive provides for the case of contributory negligence, in which liability of the producer may be reduced or excluded where damage is caused by the defective product as well as by the injured party's negligence or that of a person under the injured party's custody (i.e., misuse of the product). ${ }^{77}$ Herein contributory fault of third parties is governed by the respective national law and falls outside the scope of the Directive..$^{7}$ Additionally, it is for national courts to decide on the extent to which the producer's liability will be reduced or excluded. 79

\subsubsection{Miscellaneous provisions}

With the aim of balancing the producer's strict liability, a limitation period of three years is applicable to any proceeding for the recovery of damages, running from the day the plaintiff has or should have become aware of the defect and the identity of the producer, which is determined with respect to the nature of each individual incident. ${ }^{80} \mathrm{~A}$ product is subject to use and thereby becomes obsolete over time, making it hard to establish whether it was actually defective at the time it was put into circulation. Therefore, in order to protect the producer, the victim's right to claim expires within ten years starting from

\footnotetext{
72 Art.7 (c) Directive 85/374.

73 Art.7 (f) Directive 85/374.

74 Art.15 (1) (b) Directive 85/374.

75 Art.7 (e) Directive 85/374.

76 O.J. No. C93, 49 (1988).

77 Art.8 (2) Directive 85/374.

78 Art.8 (1) Directive 85/374.

79 Bianco 2002, p.105.

80 Art.10 Directive 85/374.
} 
the date on which the product causing damage was put into circulation..$^{81}$ In addition to time limits, the Directive provides an optional limitation to maximum liability for death and personal injury at seventy million ECU..$^{82}$

Strict liability is not absolute. The injured party has to prove (a) damage other than damage to the product itself, and (b) that such damage would not have occurred but for the defect in the product, thereby establishing a causal link between the damage and the defect in the product, lies with the injured party. ${ }^{83}$ Consumer protection remains one of the principle aims throughout the Directive, as the directive's field of application is restricted to damages causing either death or personal injury and damages to "consumer property", and excludes "commercially used" property as well as non-material damage from its scope. ${ }^{84}$ Consumer property hereby refers to any item of property other than the defective good itself, valued higher than $€ 500$, ordinarily intended for private use or consumption and primarily used by the injured party to satisfy personal demands. ${ }^{85}$ One should note that the Directive does not stipulate whether damage caused by death or injury is to be compensated in full or partially; it is therefore left to national law to determine. ${ }^{86}$

\section{Directive $85 / 374$ and its chance of becoming the sole source for liability for defective products}

\subsection{Article 13 and the Harmonisation Paradox}

The Directive has been implemented over and above a system of sophisticated causes of action constructed by courts and scholars within the different national systems. The question therefore becomes how the Directive interacts with preexisting actions. Article 13 of the Directive stipulates, "The Directive shall not affect any rights which an injured

81 Art.11 Directive $85 / 374$. The time limit is absolute in consideration of the producer's burden of proof according to Art.7 (b) as with time it will become more and more difficult to determine whether the defect existed when the product was put into circulation.

82 Art.16 Directive 85/374. Whereby in accordance with Art.18 ECU shall be determined by reference to Regulation (EEC) No.3180/78 (1), as amended by Regulation (EEC) No.2626/84 (2).

83 Art.4 Directive $85 / 374$

84 Art.9 Directive $85 / 374$.

85 Art.9 (b) (i) (ii) Directive 85/374.

86 Hunter et al. 2001, p.404. 
person may have according to the rules of the law of contractual or non-contractual liability or a special liability system existing at the moment when this Directive is notified." The Article, generally perceived as to permit the co-existence of parallel contractual and tortious actions and allowing them to evolve over time, has been subject to detailed analysis by the ECJ confirming the maximal harmonisation character of the Directive. ${ }^{87}$ In its decisions in Commission v France and González Sánchez v Medicina Asturiana SA ${ }^{88}$ the ECJ primarily relied on an analysis of the Directive's legal basis under Article 100 (now Article 115 TFEU), which, the court stated, provides "Member States with no possibility to maintain or establish provisions departing from the instrument" ${ }^{89}$ The court added that "the degree of discretion available to Member States therefore is determined by the provisions of the Directive itself; one therefore needs to point to the first recital [...] the purpose of the Directive is to ensure undistorted competition, facilitate the free movement of goods and to avoid divergences in the levels of consumer protection". 90 The court therefore concluded that Article 13 does not permit the maintenance of a general product liability system other than the one provided by the Directive. ${ }^{91}$ Nonetheless, according to the ECJ, Article 13 must be interpreted as "not precluding the application of other systems of contractual or non-contractual liability based on other grounds, such as fault or a warranty in respect of latent defects" 92 moreover "the rights a party may rely on under a special liability regime must be construed [...] as referring to a specific scheme limited to a given sector of production." ${ }^{93}$ An example is the German Arzneimittelgesetz (Drug Act)94, which applied to defective medicines and was the only special product liability regime in Europe that was already existing when the Directive took effect and which was thus exempted by Article 13 applicable in cases of defective medicine. ${ }^{95}$ Referral to "other grounds" hereby most likely relates to everything but liability based on loss or

87 Quotations throughout this paragraph are from C-52/oo Commission v France [2002] ECR I-3827. The same wording is used in C-183/oo González Sánchez v Medicina Asturiana SA [2002] ECR I-3901 para.23-32.

88 C-52/00 Commission v France [2002] ECR I-3827, para.24.

89 C-52/00 Commission v France [2002] ECR I-3827, para.14.

90 C-52/00 Commission v France [2002] ECR I-3827, para.18.

91 C-52/00 Commission v France [2002] ECR I-3827, para.21.

92 C-52/00 Commission v France [2002] ECR I-3827, para.22.

93 C-52/oo Commission v France [2002] ECR I-3827, para.23.

94 Van Dam 2006, p.376.

95 Lenze 2005, p.119. 
harm caused by putting a defective product into circulation..$^{96}$ This inevitably means that victims may continue to claim under previously existing tortious and contractual actions.

One therefore has to consider the added value provided by the Directive to the consumer. The drafters of the Directive believed that, in comparison to pre-existing actions, the Directive would provide a more favorable position to victims and therefore, that it would in practice become the sole basis for liability claims for defective products.97 However, a 2002 study by Lovell illustrated that in the majority of countries there is a prevailing perception that the Directive was only rarely relied upon as the sole basis for product liability claims, while the majority of claimants continued to use parallel regimes..$^{98}$ The third Commission report in 2001 counted, in line with national reports and findings provided by jurists from several countries, less than hundred court decisions under the new regime, sixteen years after its adoption in all Member States. ${ }^{99}$ The Lovell study added that, although there had been a slight increase in the number of product liability claims in general since 1985 , factors that influenced this increase were consumer awareness of rights and easier access to information rather than the existence of the Directive. In sum, victims have largely neglected the Directive. This most likely is the result of the Directive's restricted scope of application and limited advantages; a consumer, by choosing to claim under the Directive would loose options, making contractual and delictual actions preserved by Article 13 more favorable, and undermining the objective of "complete" harmonisation. In this context one may be critical as to the added value provided for by the Directive. Moreover, given that the Commission is aware of these facts but concludes that the Directive functions properly in practice makes one wonder what impact the Commission really envisioned for the new regime.

\subsubsection{The empty promise of Directive 85/374 from a European Consumer's perspective}

A comparison of the Directive with former national regimes reveals that the new law does not advance the position of the consumer. Liability under the Directive, like generic tort and contractual liability, certainly is not absolute; the consumer still is required to prove damage, defect and causation, and the provision of a consumer expectation test as well

\footnotetext{
96 Fairgrieve 2005, p.238.

97 Taylor 2005, p. 222.

98 Lovell 2003, p.37.

99 Commission 2006, p.10.
} 
as recognition of several defenses create considerable loopholes..$^{100}$ In practice, proving the existence of a defect can be equally or more challenging than establishing fault on part of the manufacturer. National authorities as well as consumer representatives emphasize that injured parties face considerable difficulties in proving that damage was caused by a product's defect. ${ }^{101}$ This is mostly due to the high economic costs involved in obtaining expert opinions and lack of access to essential information, especially in case of highly technical products, as well as proving the causal link where alleged injuries are of a complex nature. ${ }^{102}$ Not having to prove fault is therefore a relatively small benefit; even more so because, save in a few incidents, no greater liability is imposed by the Directive than under traditional tort or contract actions, which in practice de facto often amount to systems of strict liability. One may point to France, where, in a number of cases during the 1990's, the Cour de Cassation developed, as compensation for the legislature's inactivity, to transpose the Directive into French law ${ }^{103}$, a strict obligation de sécurité. ${ }^{104}$ The extent of the latter is remarkable; it imposes a security obligation on the manufacturer or intermediate reseller, therefore a guarantee that products sold provide the necessary level of security expected by consumers, on the manufacturer or intermediate reseller of a chose. ${ }^{105}$ This duty exists through the action directe doctrine independent of any contractual obligation ${ }^{106}$ and is owed to the buyer (contractual) as well as, in accordance with Article 1382 of the Civil Code to all third parties suffering damage. ${ }^{107}$ Hence, the protection offered is equal to or even exceeds the Directive, placing a greater burden on the manufacturer and seller of a defective product.

100 Reimann 2003, p.150.

101 Commission 2011, p.7

102 Commission 2011, p.8.

103 Taylor 2005, p. 234-235. Although the action is nominally based on the Articles of the French Civil Code, the Cour de cassation follows the wording of and uses the liability rules established by the Directive centering determination of liability on the notion of defect.

104 Koch 2010, p.185. Refers to Articles 1147 for buyers, articles 1382 and 1284.1 for third party victims. Sometimes also Article 221-1 of the Code de la consummation, on product safety.

105 Fairgrieve 2005, p.5

106 Taylor 2005, p.232. French case law hereby developed to provide that contractual action to bring claims for the failure to deliver safe products attaches to the product and hence passes to the downstream buyer or user circumventing problems associated with privity of contract.

107 Cass.civ.1re, 3 March 1998, JCP G 1998.II.10049, Rapp. P. Sargos; Cass. Civ. 1re, 28 April 1998, JCP G 1998. II.10088, Rapp. P.Sargos. The only real defense available is the one of force majeure but nothing like the development risk defense. 
Additionally, remedies designed pursuant to the Directive provide several limitations; firstly, under the Directive primary liability arises for the manufacturer whereas liability of the supplier is perceived as subsidiary liability. Similarly, in the earlier mentioned judgment Commission v France the court precluded national legislation creating liability for intermediaries on the same basis as manufacturer liability under the Directive i.e. strict liability, save for instances listed exhaustively by Article 3 (3). ${ }^{108}$ This approach often seems confusing to courts and victims alike, and in 1999 the Spanish Court of Appeal found the supplier jointly and severally liable with the manufacturer and its insurance company; ${ }^{109}$ the Commission Green paper also proposed to extend liability to any professional whose actions affected the safety properties of a product placed on the market. ${ }^{110}$ Moreover in 2002, responding to the ECJ judgment, the Council suggested that the Directive should be amended so as to allow Member States to provide rules governing intermediary liability based on strict liability, given the fact that supplier liability is not per se addressed and consequently falls outside the scope of maximum harmonisation."1

The Commission, nonetheless, rejects such reforms, arguing that an extension would lead to a multiplicity of actions that should be avoided. ${ }^{112}$ Accordingly consumers are deprived of a particularly favorable element. Indeed the few cases that reached the French courts so far under the implementing instrument concern the liability of supplier rather than manufacturer.113

National laws on the other hand provide a wider scope of potential defendants. For example, in Germany most product liability cases, until now, have been brought in tort, on the basis of a breach of a duty of care under $\$ 823$ BGB, which may attach to all persons involved in the production or marketing of the product including the supplier (regardless whether the manufacturer can be identified) ${ }^{14}$ but also members of management, designers, retailers and even inspectors, regulatory bodies and governmental departments,

\footnotetext{
108 C-52/00 Commission of the European Communities v French Republic [2002] I-03827, para.39.

109 SAP Badajoz 8.4.1999 [AC 1999/674]. For damage caused due to a leaking butane gas cylinder attributable to a manufacturing defect.

110 COM [1999] 396 final, p.29.

111 Directive 85/374/EEC. OJ C26, 4.4.2003, p.2-3.

112 C-177/04 Commission of the European Communities v French Republic [2006] I-2461, para.53; C-402/03 Skov Afg v Bilka [2006] I-00199, para.28. See also: Commission 2006, p.11.

113 Taylor 2005, p.227.

114 BGHZ 139, 43 (Fireball I) and BGHZ 139, 79 (Fireball II).
} 
who may be found jointly or personally liable without any order of priority. ${ }^{115}$ Interestingly, Italian law allows for the non-concurrence of contractual liability and civil liability for the same injury, and therefore it does not matter whether one party is sued under contractual law and the other under product liability law. ${ }^{16}$ Under the Directive joint and several liability is limited to persons liable for the same injury "under the Directive's provisions". ${ }^{17}$ By not imposing this limitation, Italian courts have provided a substantial benefit to victims by extending the number of liable persons, allowing victims to combine all possible lawsuits for the same damage. ${ }^{118}$

National laws also provide a significant advantage in terms of time limits. The temporal scope of liability under the Directive is limited to ten years from the date on which the product was put into circulation. ${ }^{19}$ However, one may question the fairness of that provision as it may remove a right to remedy before damage has even occurred, and inevitably leads to injustice in terms of particular production sectors identified to bear latent injury that cause damage only after the ten year window, even more so considering modern technological advances. ${ }^{120}$ One may think of long incubation periods of dangerous substances or pharmaceutical side effects that manifest only in the long run or, referring to the Dutch DES case, that are felt by the next generation. ${ }^{121}$ It comes as no surprise that the Commission has neglected this matter so far in its reports. ${ }^{122}$ National limitation periods provide a more favorable alternative ranging up to thirty years, with periods running from the date of the damage or when the victim became aware of it. ${ }^{123}$ One should also note that in several jurisdictions such as France these periods in terms of contract law are subject to judicial discretion and depend on e.g. the nature of the defect, whereby one often detects a

115 BGHZ VersR 2001, 381 (Toddler Tea IV); BGH NJW 1975, 1827; BGH NJW 1987, 372.

116 Trib. Milano 23-3-1996, I contratti, 1996, 374.

117 Art.5 Directive 85/374.

118 Rajneri 2005, p.75, 79.

119 C-127/04 O’Byrne v Sanofi Pasteur MSD Ltd. [2006] 2 CMLR 24.

120 Commission 2000, p.20-21

121 Hoge Raad 9 October 1992, NJ 1994, 535, comm. note CJHB (DES v Daughters). Concerned the liability of a large number of potential plaintiffs, by putting a defective product on the market namely DES, a medicine destined to protect against premature birth, taken by pregnant women from the 1940's to the beginning of the 1960's. However children born appeared to suffer from fertility problems and daughters had a high risk of cervical cancer.

122 Fairgrieve \& Howells 2007, p.977.

123 Art.2262 Code Civil for contract and Art.2270-1 Code Civil for delictual actions. 
pro-consumer attitude of judges. ${ }^{124}$ Additionally, the new regime does not apply to damage occurring before the product is circulated. Therefore, victims of such damage will have to rely on pre-existing actions. This applies to the majority of product liability cases in France where the implementing instrument entered into force only in $1998 .{ }^{25}$

Additionally the Directive's scope of application is limited in terms of recoverable damages. Unlike national actions in tort and contract, compensation under the Directive is restricted to consequential loss, i.e. economic loss antecedent to personal injury or property damage of the claimant, excluding damage to the product itself, pure economic loss, nonmaterial damages and property damage less than $€ 500 .{ }^{126}$ In the context of compensation for non-pecuniary losses, the ECJ ruled that it was left to the Member States to decide on the precise content of the heads of damages mentioned by the Directive, without prejudice to non-material damage, which according to Article 9 is to be determined by national law, as long as full and proper compensation for injured persons is available and application of national rules do not impair the effectiveness of the Directive. ${ }^{127}$ This requires national laws to be interpreted in light of the purpose and wording of the Directive. ${ }^{128}$ Given the broad margins set by Article 9, the availability of pecuniary and non-pecuniary remedies as well as the amount of pecuniary damages are still largely dependent on the applicable law of damages. ${ }^{29}$ National provisions regarding damages differ from country to country, but it is generally difficult to argue that they impair the effectiveness of the Directive as long as they provide some sort of compensation to victims of defective products. ${ }^{130}$

\subsection{Differing interpretation of Common Concepts - Application of the notion of defect across Europe}

The choice of how to protect consumers and of which remedies to provide for victims of defective products is a policy question directly related to the perception of 'justice' in a given society, hence a question whose answer may vary according to the moral and cultural values of such community. Therefore, in order to achieve complete harmonization

\footnotetext{
124 Boger 1984, p.8. See art.1648 French Code Civil.

125 Art.7 (a) Directive 85/374.

126 Art.9 Directive 85/374

127 ECJ 10 May 2001 (C-203/99) Veedfalds v Århus Amtskommune, para.27. ECJ 15 May 1990, (C-365/88) [1990] ECR I-1845 (Hagen GmbH v Zeehoge) para.20.

128 C-14/83 Von Colson and Kamann [1984] ECR 891, para.26.

129 Van Dam 2006, p.343.

130 Van Dam 2006, p.382.
} 
of substantive rules, one has to ensure that the values entailed in the European instrument and those of the Member State coincide. The Directive provides the substantive law. However it is national courts that interpret the provisions along the lines of national concepts, language, and political, socio-economic and cultural backgrounds. This is even more evident where the rule provides for general rather than specific concepts, as is the case for Directive 85/374. ${ }^{131}$

The concept of defectiveness leaves a lot of room for argument and uncertainty, and one detects discrepancies in the way courts have approached the concept. While the Directive on its face has retained a single standard to determine defectiveness, there is consensus within Europe that not all product deficiencies are the same, which led courts to distinguish between manufacturing, design and instruction defects. While design and instruction defects refer to shortcomings inherent in the product affecting each unit of production, manufacturing defects refer to an individual product that fails to meet the standard of quality of its particular type. ${ }^{132}$ This has far reaching consequences as, in practice, courts limit the application of strict liability to manufacturing defects, while negligence principles have gained the upper hand in design and instruction defects. ${ }^{133}$

As has been pointed out, in light of the Directive, European courts are bound to refer to a "consumer expectations" test whereby a product is defective if it does not provide the safety a person is entitled to expect. However, a major difficulty with the definition provided by Article 6 is its opaque nature that fails to provide clear-cut objective standards to measure the safety of a product. ${ }^{34}$ One could argue that included within the definition is the very question to which the definition should be providing the answer. To determine defectiveness "all circumstances" including presentation of the product, expected use and date of circulation need to be considered. One obvious question that arises is whether comments made by the salesmen qualify as presentation of the product? Such questions are left unanswered. Therefore national courts have to delineate these uncertainties on their own, exercise, which is likely to provide dissimilar results. Given such an openended standard, in which only a few relevant factors are provided, many issues are left for assessment by national judges who can adopt almost any interpretation. Consistent application of such a standard seems illusive in a culturally diverse Europe as consumer expectation will be determined in light of the particulars of a given case and will be

131 Van Dam 2007, p.72.

132 Van Dam 2006, p.377.

133 Lenze 2005, p.108.

134 Huber \& Litan 1991, p.42. 
influenced by the general perception of safety held by the particular country. ${ }^{135}$ Uncertainty prevails, as the Directive is unable to provide guidance to manufacturers and consumers as to whose expectations govern. Is it the expectations of those present in the consumer's home jurisdiction or rather the standard, where applicable, in the jurisdiction where the product was first circulated that governs? ${ }^{136}$ Reasonable consumer "expectations" are determined by a particular country's perception of safety and therefore vary. How does e.g. a German judge assess the consumer expectation governing the sale of a German product whose alleged defect subsequently causes harm to an Italian consumer? In this context there has been debate on whether the strict liability regime imposed by the Directive covers design defects, or whether liability under the Directive merely amounted to a form of super-negligence with little difference in practice from negligence. ${ }^{137}$ Those that plead for the latter describe the instrument as "superficially strict, but substantially fault based."138 They find support in the Reports of the Commission itself, which states, e.g., "difficulties encountered by claimants 'in proving fault' have been redressed by national courts' generous attitude to declaring a product defective when it does not provide the safety which a person is entitled to expect". ${ }^{39}$ The Commission cites a series of national cases during the late nineteenth and early twentieth centuries that showed the uneasiness of judges toward traditional negligence, whereby courts come either to an expansive interpretation of the term defect, or reverse the burden of proof of fault by application of the so-called res ipsa loquitur rule, as they feel compelled to compensate victims. ${ }^{140}$ Such a citation seems perplexing in light of the Directive's premise that the standard of defectiveness does not require proof of "personal blameworthiness" on part of the producer, and also shows how easily national courts apply the language of negligence in order to determine defectiveness.

National courts seem to agree that in case of manufacturing defects, liability is strict and that there is a judicial tendency to assume carelessness. Therefore, in practice, manufacturers

135 Corr 1990, p.239.

136 lbid.

137 Stapleton 1994, p.49.

138 Van Wees \& Brookhuis 2005, p.358

139 Fairgrieve \& Howells 2007, p.968.

140 Grant v Australian Knitting Mills [1936] AC 85. Court applied the res ipsa loquitur or circumstances speak for they rule. Fowlpest case $\mathrm{BGHZ} 51,91$. If the cause of damage can only be located within the premise of the producer he is presumed negligent. See also: Decision Tribunal de Grande Instance in Aix-en-Provence of 2 October 2001. Dalloz 2001, 3092; Court of Appeal of Toulouse Decision of 7 November 2000, No 1999/03960; Trib. Roma 3 November 2003, in Danno e Responsabilità, 2004, 529; Decision of the Austrian Supreme Court (OGH 22.10.2002 10 Ob 98/o2p. 
are generally unable to defend themselves by arguing that they took reasonable care in the production and marketing of their product, favoring the consumers' expectations about the absence of hidden defects. ${ }^{141}$ However, in cases of design or instruction defects, especially in the context of complex and innovative products, the test does not guide courts in their assessment since it is questionable whether a consumer was able to form an accurate expectation at all, as they generally lack experience and knowledge to delineate an expected standard of performance. ${ }^{142}$

Design defects provide difficulties in that there is no comparator to judge the product against, and often one has to balance an array of competing factors. ${ }^{143}$ Courts often will take account of existing statutes, regulations and safety standards. ${ }^{144}$ Moreover the consumer expectation test implies that otherwise unsafe products will not be considered defective if adequate information and warnings have been provided or where the danger was obvious. ${ }^{145}$ There is a substantial bulk of case law suggesting that the safer-design alternative test enumerated in Article 6 (2) of the Directive lies at the heart of every design-defect analysis, as it deals with the change in the public's perception towards risk. ${ }^{146}$ Hereto courts, when determining the standard of safety which persons are entitled to expect, adopt a more subjective approach using negligence principles by way of weighing the magnitude and gravity of risk with the cost of precautions and social utility. ${ }^{147} \mathrm{~A}$ product will be defectively designed and fail the consumer expectation tests where its risk outweighs its benefits and where such risk could have been avoided by an alternative design. ${ }^{148}$

\footnotetext{
141 Van Dam 2006, p.377.

142 Baum 1988, p.10.

143 Fairgrieve \& Howells 2007, p.967.

144 OLG Düsseldorf, 20.12.2002, 14 U 99/o2 (Chocolate Bar case).

145 Flear et al. 2013, p.188.

146 Abouzaid v Mother care [200o] All ER (D) 2436, para.27; Austrian Supreme Court, Decision $\mathrm{f} 5$ December $2002-8$ OB 192/99i (Extension Ladder) = 13 (2003) European Product Liability Rev.; Decision of 19 September 2002 - 3 Ob 71/O2 s (Industrial Machine). Beschl.v. 19.09.2002 - 3 OB 71/O2 s.

147 HR, June 30,1989 , NJ, 1990, nr. 652 (Halcion case). In this case the Dutch Supreme Court balanced the low frequency of the adverse effects of Halcion, a sedative, and its usefulness against the severity of resulting injury and the existence of alternative; BGH, July 11, 1972, NJW, 1972, 217. The German Supreme Court considered the degree of dangerousness of the product, the financial consequences of a design chance and the nature and severity of any risk.
}

148 Iman Abouzaid v Mothercare (UK) Ltd [2002] WL 1918530. 


\subsubsection{The Abstract Approach: the case of A and others v National Blood Authority}

The judgment in $A$ and others $v$ National Blood Authority and others, ${ }^{149}$ central to any discussion of the English approach to defectiveness, followed a different path from earlier decisions in the United Kingdom, demonstrating a firm commitment to the realization of the purposes intended by the Directive. ${ }^{150} \mathrm{Mr}$. Justice Burton argued in favor of a consumer "legitimate" expectation test. A general lack of provisions from which a theory of strict liability could be built afforded Burton the opportunity to be creative; he thus created a policy by way of interpreting concepts whose function had not been explained by their author, nor provided with a structure of internal coherence. ${ }^{151}$ In his opinion the goal of protecting life, limb and, to some extent, property of the consumer corresponds to the notion of safety rather than utility. Safety does not refer to what is actually expected by the public at large but what they are entitled to expect. Consumer expectations are subject to a reasonableness test. ${ }^{152}$ It is the Nobile officium of judges to determine the defectiveness of a product, acting as an informed representative of the public at large. ${ }^{153}$

Burton seemed keen to counter the abovementioned pessimism that strict liability under the Directive amounted merely to a test of negligence, requiring some kind of riskutility balancing when challenging a design or instruction defect. He argued that account needed to be taken of general perceptions of safety legitimately held by the public towards the product in question. Legitimate expectations hereby refer to the quality of the product as such not whether the producer was reasonable and has taken all necessary and available precautions. ${ }^{154}$

After Burton made explicit that inquiry should be product rather than producerorientated, he engaged in the determination of legitimate consumer expectation. To

149 A and others v National Blood Authority and others [2001] 3 All ER 289. Case involved claims from 114 persons infected with Hepatitis $C$ virus following blood transfusions. Claimants were infected at the time when the existence of the virus was known but no test to screen the blood was available. Therefore the claimants sought damages from the National Blood Authority (NBA) who on the other hand argued that the product was not defective as the public was entitled only to expect that the blood would not be affected by any reasonable detectable contamination.

150 Williamson 2003, p.3. Also worth noting is that Burton referred to the wording of the Directive directly rather than that of the Consumer Protection Act.

151 See Sam Bogle and others v McDonalds [2002] EWHC 490. The Court unfamiliar with the concept of strict liability relied on elements of fault liability.

152 Richardson v LRC Products [2000] 59 BMLR 185.

153 Bartle, 1989. Cited by A and other v National Blood Authority and other [2001] 3 All ER 289. para.31.

154 A and other v National Blood Authority and other [2001] 3 All ER 289, para.32. 
this end he introduced a formula that was based on a distinction of standard and nonstandard products rejecting the traditional distinction of manufacturing, design and instruction defects which, according to Burton, failed to cover or did not appropriately characterize all defects that might arise. ${ }^{155}$ While standard products function as intended, non-standard products are deficient in safety terms because of harmful characteristics (not present in the standard product) that cause material injury or damage. ${ }^{156}$ Therefore, comparing the products in question with other products of the same type, namely the bags of blood containing the (then-undetectable) Hepatitis $C$ virus with other bags of blood from the same producer that did not contain the virus, led to the conclusion that the contaminated blood products had to be regarded as non-standard. Burton dismissed as "philosophical" the proposition that all blood products should be regarded as carrying the same risk and were therefore, as standard, equally defective. ${ }^{157}$ Hereafter the test considers whether the public at large accepted the non-standard nature of the product, i.e. that a proportion of the products is defective. ${ }^{158}$ As to the latter, Burton ruled that "all the circumstances" in Article 6 of the Directive referred to all relevant circumstances; he held that the conduct of the producer and therefore the unavoidability of the defect were irrelevant to the test of consumer expectations. ${ }^{59}$ Burton's assumption finds support in other judgments within the European Community, which considered that provision of the Directive clearly framed so as to exclude consideration of the producer's conduct at any stage e.g. the German Bottle Case ${ }^{160}$ as well as Scholten. ${ }^{161}$ Burton concluded that the infected non-standard products were unsafe and, in absence of a warning to the public about the risk of infection, were not what the public was legitimately entitled to expect and were therefore defective.

In his judgment Burton seemed keen to provide an analysis that suggested a physical defect. However, this sits uneasily with his analysis of why legitimate expectations had been defeated. The analysis also does not have serious implications for cases where products have

155 Williamson 2003, p.5.

156 A and others v National Blood Authority and others [2001] 3 All ER 289 para.36.

157 Howells 2005(2), p.144

158 A and others v National Blood Authority and others [2001] 3 All ER 289, para.68.

159 A and others v National Blood Authority and others [2001] 3 All ER 289, para.32.

160 BGH 9 May 1995, BGHZ 129, 353 = NJW 1995, 2162 = JZ 1995, 1060 (German Bottle Case) German Federal Court found that the fact that it was not possible to detect and repair a fine hairline crack in a bottle that caused it to explode did not alter the consumers expectation.

Rb. Amsterdam 3 February 1999, NJ 1999, 621 (Scholten v Sanquin of Blood Supply) 
a potential to cause harm, but where the risk has not yet materialized. ${ }^{162}$ The factor that determined liability was that National Blood Authority had not engaged with the public to raise awareness of possible risks of contamination, rather than the condition of the product itself. The question of defectiveness therefore turns on whether the general public has been adequately warned. ${ }^{163}$ Therefore Burton's keenness on distinguishing negligence from strict liability, in fact, had been circumvented by the use of warnings. In most cases therefore warnings will undermine the strictness of the regime imposed by the Directive. ${ }^{164}$

The true value of the judgment lies, arguably, in the ability to account for general safety perceptions reasonably held by the general public. Risk attaches to the product that does not provide the safety that could in all circumstances justifiably been expected by the public. Safety expectations hereby do not relate to statistical expectation, but to legitimate individual expectations. ${ }^{165}$ The blood in the case could not have been made any safer however still the manufacturer was held liable as the public would not have expected it to be infected but would have expected to be informed of the risk. Adopting the abstract "legitimate expectations" approach, which is based on defeated safety expectations rather than on the identification of a particular harmful characteristic, will help to overcome evidential difficulties illustrated in previous case law. ${ }^{166}$ Previously, claimants struggled to prove a defect, as judges considered it to be insufficient to show that a product "merely failed in a way which is unsafe and contrary to general consumer expectation", requiring them to show on the preponderance of the evidence that a defect existed and its nature. ${ }^{167}$ Requiring claimants to prove how their legitimate expectations were defeated would be contrary to the idea of strict liability. Moreover such an approach would be a useful tool to bring the English theory into line with the more pro-claimant practice that seems prevalent in Europe, namely readiness to presume defect and a causal

162 Howells 2005(2), p.144.

163 Worsley v Tambrands [2000] PIOR 95. Warnings often provided through appropriate labeling so in the case the manufacturer as able to avoid liability by pointing towards warnings that tampons can cause toxic shock syndrome and having provided appropriate instructions for use. Defectiveness is concerned with the provision of minimum safety standards whereby it is irrelevant whether better warnings and instructions could have been provided as long as they meet the minimum standard.

164 Howells $2005(2)$, p.139.

165 Van Dam 2005, p.129

166 Decision of Kennedy J in High Court, 2 February 2000 Richardson v LRC Products Ltd [2000] PIOR 164; Decision of 19 April 2000 Foster v Biosil [2000] 59 BMLR 178; Decision of Field J 25 March 2002 Sam Bogle and others v McDonalds [2002] EWHC 490.

167 Howells $2005(2)$, p.148. 
link by the fact of the damage caused, and thus would contribute to a more harmonious development of European product liability. ${ }^{168}$

\section{Reconsidering feasibility of harmonisation efforts within the Area of Product liability}

As becomes apparent from the previous sections, in its current form the Directive will not be able to achieve complete harmonisation of marketing conditions. This corresponds to the conclusions drawn by the Commission itself in its recent Reports on the functioning of the Directive, wherein it appears to accept the existence of disparities in the application and interpretation of the Directive by national courts of key issues including the core concept of defectiveness. ${ }^{169}$ Nonetheless the Commission seems impassive, arguing that there is no need to engage, as there is little evidence that those disparities actually present significant obstacles to trade and consequently are unlikely to distort competition within the EU. The Commission uses the same argument to reject harmonisation in a broader sense. ${ }^{170}$ This to many authors has come as a surprise given the Commission's earlier position on the matter, but also because it runs contrary to earlier mentioned ECJ case law that confirmed the interpretation of the Directive as an instrument of maximum harmonisation.

In this context it will become important to reassess the proper division of competences concerning the regulation of product liability to determine the accurate role of the European legislator within this area. To what degree does the EU internal market require product liability rules to be harmonized? In light of the significance of current obstacles to effective harmonisation one may question the feasibility of complete harmonisation within the area of product liability.

\subsection{Regulating product liability: an exclusive European task?}

The Directive has been introduced as an internal market measure, on the basis of Article 115 TFEU. It has been questioned in how far the issue of product liability relates to the common market project, however Article 114 (3) TFEU supports the establishment of a framework of consumer laws, wherein the Union's task is to strengthen consumer

168 Fairgrieve \& Howells 2007, p.970.

169 Commission 2006, p.8-12.

170 Commission 2011, p.11. 
protection. Hereto Article 169 (2) (b) TFEU confines the EU's competence to "support, supplement and monitor national consumer laws".

In addition, pursuant to Article 114 TFEU harmonisation proceeds in so far as divergences between national laws frustrate the functioning of the internal market. A measure adopted under Article 114 TFEU must aim at eliminating (potential) barriers to trade or preventing distortion in competition. ${ }^{71}$ Nonetheless the court has adopted the view that creation of an internal market extends beyond merely removing obstacles to trade, thereby acknowledging that the Union has a certain degree of freedom as to which level of protection to adopt once it has demonstrated that approximation would genuinely improve conditions for the functioning of the internal market. ${ }^{172}$ It would, however, be farfetched to conclude that competence to regulate a matter lies exclusively with the Union, leaving no scope for more protective national consumer law. In its case law the European court clearly rejected the assumption that the Union had a general regulatory power. ${ }^{173}$ Indeed the Union lacks exclusive jurisdiction in this policy area; competence is shared in accordance with Article 4 (2) (f) TFEU.

\subsection{An economic analysis into the feasibility of full harmonisation within the area of product liability}

The Commission as well as the CJEU has advanced several economic arguments in order to justify the need for full harmonisation within the area of product liability. Hereby they refer to the necessity of equalizing the conditions of competition within Europe, creating an equal commercial playing field thereby encouraging cross border trade, by eliminating disparities between the laws of the Member States that were deemed to distort the internal market. From an economic point of view though, maximum harmonisation is not justified; there is no reason why product liability laws need to be uniform as long as they are brought together within sufficiently narrow bands of compatibility so as not to distort competition. ${ }^{174}$ One may be sceptical as to the extent to which divergent product liability rules have a detrimental direct effect on trade; while it might be accepted that differences

171 C-58/08 Vodafone, 02 et al v Secretary of State [2010] ECR I-5026. There must be an "appreciable distortion". Mere divergence between national rules, which would be removed by way of a Directive, is not enough to justify approximation.

172 Howells 2006, p.67.

173 C-376/98 Germany v European Parliament and Council of European Union (Tobacco Advertising I) [2000] ECR I-8419 para.179. Community should be guided by the principle of a high standard of consumer protection.

174 Howells $2005(1)$, p.238. 
in applicable liability laws will affect decisions as to the design of a product or the conditions of marketing as producers produce products that correspond to their expected liability, one may find it hard to see how they can be categorized as distorting competition as they do not impose some particular standards, but merely punish traders for circulating defective products. The mere fact that different states hold different preferences in respect to their laws on product liability, and products cross national borders does not warrant centralization. ${ }^{175}$ As to the latter one may presume that the transboundary character of externalities, e.g. where non-pecuniary losses, not covered by the Directive, are unsatisfactorily compensated under national law, would provide a strong case for centralization ${ }^{176}$; but this would only be the case where consumers would not be able to bring action against foreign producers that market harmful products, who were protected by lenient liability regulation in their domestic country. Yet in reality manufacturers of defective products are generally liable for injury suffered in export markets, and victims are generally able to file suit within the EU against manufacturers for harm caused in another country. ${ }^{177}$

Another argument often proposed in favor of harmonizing marketing conditions is that there is a risk of a "race to the bottom" whereby in absence of full harmonisation, Member states will compete with lenient product liability laws to attract industry. However there is no evidence of such destructive competition; one may doubt whether product liability laws significantly influence a business choice for or against a given state..$^{78}$ Moreover, especially in regard to manufacturing industries that focus on export, exposure to liability law will depend on the legislation of the country where the harm occurred.

A related argument, used exhaustively by the Commission and more closely connected to the desire of creating a common European market, is the one of levelling the playing field for European industries, assuming that the creation of total equality of conditions of competition is a precondition for the functioning of the internal market. Complying with legislation imposes transaction costs; therefore in face of different product liability regulation within the Member States, competition is not equal. ${ }^{179}$ The Commission seems

175 Faure 2000, p.478.

176 Faure 200o, p.492.

177 Eger \& Schäfer 2012, p.207. This argument presumes that in case of transboundary externalities states would not have the incentive to impose stringent regulation on their own citizens as consequences of their harmful actions are felt only outside their territory.

178 Kramer \& van Rhee2012, p.81.

179 Faure 2000, p.480. 
to hide behind, and make abuse of, the image of the under-confident businessman who in absence of maximum harmonisation will be reluctant to engage in cross border trade due to the risk of different liability regimes. ${ }^{180}$ The Commission's assumption is based on several misconceptions; firstly one may argue that the attainment of a single market in all products is illusive and market conditions are never equal - even if product liability laws were completely harmonized, differences in e.g. access to justice which are left by the Directive to be determined by national law, still would not lead to a level playing field; moreover a market in which conditions of competition are in equilibrium implies no trade. ${ }^{181}$ Thus maximum harmonisation will not preclude all possible factors diverting marketing conditions. Also, such argumentation lacks concrete scientific evidence that should be provided by the Commission to support centralization. ${ }^{182}$

There is an error in the assumption that differences in marketing conditions are inevitably disruptive, as has been shown by the US experience clearly proving that a single market does not require complete unification of product liability laws. Several authors moreover argue that the validity of the distortion argument diminishes due to the fact that small differences in insurance premiums that cover product liability risks do not support the assumption of a far divergence of marketing conditions. ${ }^{183}$ One may argue that the Directive itself provides an impediment rather than a cure, e.g. through providing Member states with options to derogate from the instrument. One may consider a situation in which companies that conduct most of their business e.g. in Luxembourg, that excluded the application of a development risk defense and has not introduced any cap on producer liability, find themselves disadvantaged in comparison to those companies that primarily deal in the UK which, has adopted a somewhat watered down version of the development risk defense and does apply liability caps. ${ }^{184}$

There is one final argument advanced in support of complete harmonisation, namely that a uniform law inevitably reduces administrative cost for businesses, by providing a more stable and predictable jurisprudence. It is however questionable whether the same holds true for the area of product liability. While product liability laws certainly will create costs for manufacturer, these costs will however be passed on to the buyer when

\footnotetext{
180 Faure 2000, p.481.

181 Van den Berg 1999, p.6.

182 Brozaityte 2009-2010, p.55.

183 Van Wassenaer \& Van Catwijk 1986, p.81.

184 Mottur 1993-1994, p.1011.
} 
purchasing the product. ${ }^{185}$ One may argue that such a line of thought neglects the fact that differentiation may provide substantial benefits; as has been shown in previous sections, in light of Article 13, the use of preexisting national actions becomes the more advantageous option for the consumers as national legislation is easily adaptable to their specific needs and preferences. ${ }^{186}$ Moreover given the fact that product liability, or private law in general, is rooted deeply in the legal culture of a state, one may suggest that harmonisation costs will be prohibitive as they outweigh the relatively small transaction cost savings gained by businesses.$^{187}$ Lastly the argument would only have merit if the Directive was actually able to achieve its goal of harmonisation and providing legal certainty. This is rather unlikely, as it has been pointed out previously; the Directive fails to provide a common standard of interpretation, therefore several notions such as the one of "defect" remain unclear and lead to different application of the law in practice.

\subsection{Coordination problems}

The Directive provides an excellent example of poor cooperation in the European multi-level system. The fact that the Directive is implemented in the Member States as an alternative to, and not a substitution of existing contractual and delictual actions seems an odd way to achieve harmonisation. ${ }^{188}$ Full harmonisation moreover is a policy with limitation, namely it is limited to the scope of regulation set by the Directive, this allows Member States to maintain or enact rules which, although dealing with the same matter, have a different legal basis and thus circumvent the purpose of unification. This in practice will allow Member States to provide similar or even more favorable rights of compensation, diminishing the actual impact of the Directive clearly contradicting with the Directives aim of unification. ${ }^{189}$ The recent ECJ case law on Article 13 illustrated earlier clearly highlights these coordination problems. The court confirmed that the margin of discretion available to Member States to regulate within the matter of product liability is determined by the Directive itself. Hereby the court pointed out that Article13 does not permit MS to maintain a general system of product liability other than the one provided for by the Directive. However even if one was to accept the maximal nature of the instrument one may disagree on this point; the question arises whether a distinction as has been

185 Van den Bergh 1998, p.137-139.

186 Legrand 1997, p.111.

187 lbid.

188 Stapleton 1994, p.54.

189 Mak 2009, p.5 
drawn by the court in Commission v France, namely one between special liability regimes and general contractual and delictual actions on the one hand and general product liability regimes on the other is possible. ${ }^{190}$ In fact using the fluid concept of negligence, courts often apply forms of strict liability close to the one provided by the Directive. There is therefore clearly a threat to national strict liability regimes that neither transpose the Directive nor can be regarded as a special sectoral liability system such as the French "obligation de securité". ${ }^{191}$ Recent opinion amongst academics is that the autonomous obligation de securité, which in practice reaches the same results as strict liability, was to be seen as equivalent to the strict liability regime imposed by the Directive; therefore it had to be reinterpreted so as to not exceed the protection afforded by the Directive. ${ }^{192}$ However this seems unwarranted, as the obligation de securité is the mere accumulation of a set of contractual and delictual rules set out in the Civil Code and therefore should be preserved under Article 13 of the Directive. Much depends therefore on the reactions to the ruling by French courts as well as the ECJ. Even though the ECJ restricts the use of parallel systems to by-pass the Directive, its rather formalistic approach is likely to prevent a ruling declaring actions such as the obligation de securite contradictory to Article 13, as formally they remain a fault liability mechanism, which clearly indicates how superficial the concerns for maximal harmonisation are. ${ }^{193}$

What becomes apparent is that a fundamental vision on the functioning and objectives of product liability law appears to be absent. The CJEU insistence on a full harmonisation approach seems imprudent; it has been shown that product liability overlaps and is influenced by a wide range of contractual and non-contractual actions but also other areas such as environmental law, and therefore cannot be easily separated nor delineated within the scope of a Directive, without also addressing the general framework of substantial and procedural rules within each Member State. ${ }^{194}$ The ECJ's insistence on full harmonisation moreover appears disproportionate; for example, under certain circumstances it will be easier for an injured party in the UK to claim unsatisfactory quality than to establish a defect under the Consumer Protection Act 1987. In this regard, does the ECJ case law intent to require Member States to reform or adopt their warranty law, because of its product liability implications? Such impediment to the development of

190 Schulze 2011, p.70.

191 Fairgrieve 2005, p.97.

192 Schmid 2003, p.7.

193 Ibid.

194 Hartkamp \& Hondius 2004, p.647. 
warranty law seems unwarranted, even more questionable is why national courts would have to change their interpretation of a law that only incidentally provides a basis for liability of defective products. 195

In its current state the Directive seems to contradict the assumption held by the CJEU. Given the premise of full harmonisation, it seems strange that the court thought it to be essential to condemn Member States for allowing consumers to recover the first 500 euros of property damage ${ }^{196}$, while it did not see the value in providing for recovery of non-material damages, although arguably the latter seems to have a more likely impact on the internal market. ${ }^{197}$ In this regard the CJEU's pursuit of full harmonisation will be counterproductive; because of the Directive's numerous lacunae essential principles of relevance to businesses and consumers are left to national law, disabling them from making their arrangements and calculations on the basis of the Directive and forcing them to rely on national law altogether. ${ }^{198}$ Moreover it will lead to a state of paralyses wherein product liability legislation is frozen in the year 1985, as the Directive sets 'the floor and ceiling' at the same time, leaving no space for Member States to liberate their laws further and react to any consumer or business preferences, thereby discriminating against those countries e.g. France that already attained the same results through an extensive interpretation of liability for fault. 199 One may refer to Frank Easterbrook arguing that 'producing a level playing field by chopping down the heights, forcing all of us to live in the valley has nothing to recommend it.'200

\section{The Future of the European Product Liability Directive}

The Directive has put in place a process of harmonisation in an area that is notoriously diverse. The regime imposed is incomplete and complementary to any of the national liability schemes and has therefore often been described by critics as a "defective

195 Howells 2005(1), p.205.

196 C52/00 Commission v France [2002] ECR I-3827 and C-154/oo Commission v Greece [2002] ECR I-3889.

197 Howells 2005(1), p.204.

198 Schmid 2003, p.6.

199 Christian Joerges 2004, p.45

200 Buxbaum et al. 1996, p.10-11. 
product" itself. In accordance with Article 21, the Directive is to be reviewed every five years. ${ }^{201}$ Until today such review has only once led to reform, namely the removal of the exclusion of agricultural goods and game. However, reports provided by the Commission have been scant and concluded no need for reform. Also, the Green Paper ${ }^{202}$, although proposing a range of possible reforms from minor to very drastic measures, lacked focus and motivation to engage in such reforms; rather the intention was to simply put these considerations out for discussion. Although not directly addressing the issue the Commission acknowledges the need to reconsider whether, in the light of the principle of subsidiarity, more powers should be transferred to the national level. ${ }^{203}$ One may find ease in following the Commissions conclusion that the Directive indeed is only one step in the long process of establishing a genuine product liability policy at community level. ${ }^{204}$

\subsection{Modernization of Directive 85/374}

The recent decisions of the CJEU demonstrate hostility towards local diversity and may be perceived as a response to the rising appeal of differentiation as guiding principle in European practice. ${ }^{205}$ Such a position is deeply rooted in the assumption that a common market needs common rules; nonetheless the contrary has been illustrated. The Commission and the CJEU should therefore review their approach towards harmonisation, if the Directive is to succeed in facilitating the internal market and harmonizing the laws of product liability it should represent a common floor of minimum rules, allowing Member states to develop their law in accordance with local preferences. As will be pointed out below harmonisation may adopt various forms and does not require laws to be identical, the EU role should become one of coordinating national laws to evolve in a similar direction, hereby providing national courts with the tools to achieve harmonisation practice as well as in theory. ${ }^{206}$

This paper has pointed towards Article 13 as an obstacle to effective harmonisation. In principle such conclusion lends support to the removal of Article 13 to achieve greater

201 Art.21 Directive 85/374. Note the options on the development risk defense and the cap on personal injuries after ten years was to be reviews after ten years in accordance with Art.15 (3) and 16 (2).

$202 \operatorname{COM}(1999) 396$.

$203 \mathrm{lbid}$, p.10. Note that the principle of subsidiarity was introduced after the Directive came into force, by the Single European Act and became a general principle through the Maastricht Treaty.

204 lbid.

205 Shuibhne 2006, p.49.

206 Howells 2006, p.72. 
harmonisation. Although one clearly sees the advantage of simplifying the law for producers/suppliers, as a political matter it remains controversial, as it would deprive consumers of the right to choose the most advantageous course of action. This would be undesirable as, unless accompanied by amendments to other features of the Directive that affect the rights of consumers e.g. facilitating the burden to prove a defect, it would reduce consumer protection in countries that provide more favorable alternatives like e.g. France. ${ }^{207}$

Although one may envision the possibility to revise the Directive to clarify concepts, any dream of more fundamental reforms vanishes due to the lack of a strong reform call; apparently the heat has gone out of the debate. The Commission seems uninterested to take on the task and re-enter the debate on product liability and is seemingly pleased with the result introduced, restricting itself to merely monitoring disparities until they 'assume greater practical significance'208 and relying on the CJEU to provide order. Interest groups on the other hand seem to have moved on to newer and higher-profiled issues. ${ }^{209}$ Therefore at best one may hope for minor reforms that tidy up the law.

One such minor change might be the deletion of the $€ 500$ threshold; the rationale for imposing such threshold, namely to prevent an inflow of small amount claims seems debatable. ${ }^{210}$ Moreover there is confusion whether it is a threshold which when exceeded allows recovery in full like in the United Kingdom or rather to be treated as a deductible, subtracted from damages successfully awarded, like in most other countries. ${ }^{211}$ The threshold is clearly an issue in countries like Finland that provide inexpensive and accessible tribunals making low-value claims particularly viable, consequently providing a unjustifiable source of problems for consumers. ${ }^{212}$

\subsubsection{Towards a common standard of interpretation -time to go soft?}

Beyond substantive law, the application of the notion of defect, and in particular the National Blood Authority case have made a nice case study for the development of EU product liability as well as European private law in general, illustrating the interrelationship

207 Taylor 2005, p.242.

208 Commission 2006, p.5.

209 Taylor 2005, p.210.

210 Fairgrieve \& Howells 2007, p.974-975. It is likely that access to justice impediments provide a greater disincentive to claim for small amounts; moreover the development of alternative dispute resolution means will inevitably resolve the problem.

211 Lovell 2003, p.50-51.

212 Ibid. 
between EU and national law highlighting not only impediments to harmonisation through different court practices but also the possibility for and willingness of courts to engage in dialogue between each other but also with the supranational level. What becomes clear is that in order to attain effective harmonisation of product liability laws, the Directive must be subject to a uniform standard of interpretation. To this end constructive steps need to be taken to clarify key terms, which arguably can only be advanced if crossborder dialogue is encouraged and enhanced.

To this end fertilization of comparative law, undertaken in legal writings and reflected in case law of national courts, will provide a useful tool, as national courts ought to aspire together towards an autonomous meaning of the Directive. One may refer to a quote by Lord Bingham in the Fairchild judgment arguing that in a shrinking world... there must be some virtue in uniformity of outcome whatever the diversity of approach in reaching that outcome. ${ }^{213}$ Harmonisation cannot solely be achieved through legislative action by implementing the Directive, but success will depend on the harmonized interpretation of the provisions by national courts, by means of an exchange of decisions applying and interpreting the instrument. ${ }^{214}$ While English courts have long been open to bilateral influence of other jurisdictions further afield than the common law, ${ }^{215}$ the phenomenon seems less conspicuous in the case law of the courts of other Member States. ${ }^{216}$ Use of comparative law poses a challenge to judges and counsel. One crucial but continuously denied aspect are language barriers within Europe that continue to preclude judges from being aware of and influenced by case law of other Member states. Commentaries on the implementation of the Directive in other Member States are rarely available in practitioners' own languages, moreover only a few are available in English. ${ }^{27}$ Also, at present many of the decisions of national courts brought under the Directive are not readily available to courts of other Member States. ${ }^{218}$

It becomes clear from this that the job of the Commission should be to ensure accessibility of such information. This provides a powerful plea for the construction of common communication structures e.g. the development of central EU database

\footnotetext{
213 Fairchild v Glenhaven Funeral Services Ltd [2002] UKHL 22, para.32.

214 Fairgrieve 2005, p.5.

215 See McFarlane v Tayside Health Board [2000] 2 AC 59,73 and 80-1; Henderson v Merrett Syndicates [1995] 2 AC 145, 184; White v Jones [1995] 2 AC 207, 263.

216 Andenas et al. 2002, p.18.

217 Stapleton 1993, p.91.

218 Lovell 2003, p.56.
} 
of decisions of courts and tribunals in cases concerning the Directive. Inevitably this would provide a valuable resource, and useful guidance for judges and lawyers when interpreting the Directive where there is no CJEU jurisprudence and little national case law, and thereby in itself contribute to greater harmony in the application of the instrument. Such a database moreover will also emphasize instances of application and enable the Commission to effectively monitor and assess the practical operation of the Directive across the EU on an ongoing basis. ${ }^{219}$ For inspiration one may refer to national initiatives like the British Institute's Product Liability Forum that offers members a helpful systematic database. ${ }^{220}$

Some useful interpretation of the Directive is clearly emerging from the ECJ; nonetheless its role in harmonizing the application of the law is narrow. Litigation advances rarely as far as to reach the court e.g. the National Blood Authority case was not appealed. One may therefore conclude that apart from actions between institutions and member states the court is dependent on the occurrence of litigation and the willingness of national courts to refer to the court for preliminary rulings in accordance with Article 267 TFEU. ${ }^{221}$ One may point to the German Mineral Water Bottle case ${ }^{222}$ where the court came to the dubious conclusion that the point of law was sufficiently clear therefore no reference was necessary, although there has been discussion on the adequacy of its view that the development risk defense does not apply to manufacturing defects. The court based its decision on the fact that Member States had been given the option to provide for such defense therefore they could also on their own initiative determine the extent of its application. ${ }^{223}$ Even if the decisions of the court were to determine a standard of interpretation mandatory for all national courts, it is not guaranteed that such standard will affect the application of the law to the facts of the case by national judges nor will it resolve all the complexities of concepts but rather merely those necessary to determine the case at hand. ${ }^{224}$ Moreover it is rather questionable whether the court will grasp chances to give full and helpful guidance. ${ }^{225}$ National courts' efforts to refrain from submitting to the court in private-law cases is possibly related to the perception that the CJEU's perspective

\footnotetext{
219 lbid.

220 British Institute of International and Comparative Law.

221 Fairgrieve \& Howells, 2007 p.19.

222 [1995] NJW 2162.

223 Andenas, Bell \& Fairgrieve 2002, p.4.

224 Fairgrieve \& Howells 2007, p.19-20.

225 Stapleton 1999, p.66.
} 
is narrowed down to the effete utile of Community law, preoccupied with maximizing the effect of EU regulation; hereby the court seems not the appropriate body for the fine tuning of product liability law, incapable of recognizing and weighing conflicting interests against one another, the function of any private law adjudication. ${ }^{226}$

\subsubsection{Improving the Quality of European Intervention: Coherence}

The Directive seems to have the problem that it follows a "top-down" approach, mandatorily imposing upon Member states an additional layer of protection, unfortunately with the mere intention to promote further harmonisation rather than less and maybe more adequate harmonisation. ${ }^{227}$

As has become apparent, European intervention has blocked further development of law; hereby the limited scope of targeted, maximum harmonisation inevitably delivers ramifications, as it will challenge the coherence of national product liability law but also private law in general. The Commission as well as the CJEU seems to have adopted a functional and fragmented approach guided by the objective of facilitating the internal market, and give little attention to the wider field of private law and its coherence. ${ }^{228}$ Private law encompasses in every legal tradition a set of principles and concepts that rely on each other to function. To this end private law rules cannot be compartmentalized; the law of product liability is complex and does not exist in a vacuum but is part of these general rules of private law and therefore should be conceptualized accordingly. While mandatory rules may be imposed providing for liability for circulating defective products, the wider framework in which they operate is provided by inter alia the general law of contract and tort law, and consequently requires consideration in any future reform. ${ }^{229}$

In this context several initiatives in Europe, intended to bring about greater uniformity of laws through furnishing a common understanding of common grounds as well as differences amongst legal systems, will attain an essential role in the development of a more coherent European product liability law. One may refer inter alia to the Principles of European Tort Law (PETL) ${ }^{230}$; a compilation of guidelines intended as common framework for further development of product liability and tort law more generally at a national as well as supranational level. While such initiatives will influence the way in which the

226 Schmid 2003, p.19.

227 Eger \& Schäfer 2012, p.222.

228 Loos 2006, p.8.

229 Mak 2009, p.9.

230 Institute for European Tort Law (ETL). 
Directive is interpreted, they also influence the way courts decide on matters excluded by the Directive such as damages and causation. ${ }^{231}$

Regrettably the Directive has not been included within the consumer acquis review process, although there are numerous overlaps with areas regulated by other Directives such as the Consumer Sales Directive. ${ }^{232}$ Such lack of coordination within the European acquis is likely to transcend to the national level and have an adverse effect on the coherence of national private law. ${ }^{233}$ What becomes clear is that as long there is a general lack of internal coherence in Community private law, systematic responsibility for product liability must remain with the Member States. ${ }^{234}$ To this end emphasis must be placed, as has been stressed earlier, on the principle of minimum harmonisation giving national legislators the possibility to integrate European law within the framework of existing national law whilst retaining room to maneuver.

\subsubsection{Europe united in unity v Europe united in diversity}

The experience of the Directive so far highlights that the biggest hurdle yet to master is cultural diversity. One cannot deny its impact on the law in practice; as has been illustrated earlier in practice the question in product liability cases often becomes how easy it will be to convince judges that a product is defective. ${ }^{235}$ On the continent judges seem readily prepared to imply a defect based merely on the fact that a product caused unexpected injury, whereas English courts seem to require more prove. Such differences follow from the different roles held by the judiciaries within the respective Member States. From a continental perspective, determination of defect belongs to the sovereign power of the judge, whose role is merely to apply the law making a determination of fact as to whether a product is defective; therefore continental judges have more leeway to decide cases in a rather cavalier manner. ${ }^{236}$ The common law approach however is rather a mixture of fact and law demanding judges to justify their decision beyond intuition. This matter of style is deeply bedded in national legal tradition and will unavoidably provide an impenetrable barrier to harmonisation. ${ }^{237}$ The Directive will still be subject to a case-by case adjudication,

231 Lovell 2003, p.57.

232 See for an in depth analysis Mak 2009, p.8-15.

233 lbid.

234 Schmid 2003, p.21.

235 Howells 2005 (2), p.152.

$236 \mathrm{lbid}$, p.149.

237 Fairgrieve \& Howells 2007, p.969. See also: Howells 2008, p.121-134. 
whereby individual judges will provide their own opinion on the facts, interpreting its provisions centrifugally to improve its fit into their national legal systems at the expense of harmonisation. ${ }^{238}$ One may refer to Hoftstede who argued "cultural values do and will continue to differ among European countries... cultures shift but they shift in formation so that differences remain"239 this means if cultural values do not converge neither do legal systems as they are the outward manifestation of national culture. ${ }^{240}$

The challenge therefore seems to be to balance the common goal of European integration with the rich European heritage of cultural diversity, of which product liability is only one facet. ${ }^{241}$ The European answer in the case of product liability, so far, has been "complete harmonisation" however as has been shown such selective intervention has at best caused irritation to the normative coherence of national private law. Remaining divergences may be seen as mirror of national preferences i.e. democratically legitimate policy choices as to how product liability law should be designed and function. ${ }^{242}$ These preferences are set aside by maximum harmonization, for example in case of the Directive, by setting a uniform consumer expectation standard. Such approach neglects that national diversity is more suitable to address the optimal level of consumer protection referring to individual preferences that, as mentioned earlier, differ e.g. in respect of consumers attitude towards risk. ${ }^{243}$ Moreover it has been illustrated that local preferences are often more consumer friendly and therefore have trumped the Directive in practice. ${ }^{244}$ As mentioned previously competence lies not exclusively with the EU but requires cooperation, therefore the approach taken by the EU, ignoring national preferences replacing them by a more global trade-off at EU level in terms of achieving an internal market, seems unjustified. ${ }^{245}$ There seems to be demand for a more flexible mechanism that merges a broader multiplicity of conflicting policies and legal traditions. ${ }^{246}$ Hereby knowledge of legal and cultural background becomes crucial; hence any prospect of harmonisation depends on the quality of underlying comparative research that is not

\footnotetext{
238 Larouche 2008. p.11.

239 Hoftstede 2001, p.255.

240 Wilhelmsson 2007, p.72.

241 Wilhelmsson 2007, p.76.

242 Larouche 2008 , p.7.

243 Paolisa 2004, p.14.

244 Larouche, 2008 p.11.

245 Eger \& Schäfer, 2012 p.223.

246 Christian Joerges, 2004 p.45.
} 
merely restricted to the systematic and technical level but rather provides a discourse on policy and cultural issues. ${ }^{247}$ As Walter van Gerven rightfully pointed out "[...] convergence of the minds of practitioners, judges and future lawyers is as important as convergence of laws. Learning of each other's legal mentalities and ways of solving legal problems is therefore of crucial importance". 248

At European level there is the prevailing presumption of diversity as something negative. However arguably the fact that different preferences lead to different policies should rather be appreciated as an opportunity for innovation, whereby States become somewhat of what Professor Jan M. Smits describes as "experimenting laboratories" 249 that, by observation of other Member States' practices, provide for adequate solutions matching the particular case of each Member state. ${ }^{25}$ Of course, this does not necessarily imply that they adopt solution that are favorable towards harmonisation, however the approach of minimum harmonisation advocated by this paper would enable national legislators to compete within certain boundaries set by law ${ }^{251}$, thereby implement EU legislation into national law while at the same time paying respect to the particularities of their national law and preferences of consumers. ${ }^{252}$ Hereby they are likely to adopt solutions that make them "look good" in a European context. ${ }^{253}$ Arguably the biggest success of the European intervention within the area of private law, including the Product Liability Directive, has been that it has lifted discussion to the European level removing the to some extent the conceptual "noise" of legal systems working in isolation. ${ }^{254}$ Within this discussion the EU is likely to benefit from the experience of individual Member states in terms of efficient and proper ways to apply and shape the law within sensitive areas like private law where legal authority of the EU is limited. This process could be facilitated by the so called Open Method of Coordination (OMC), introduced by the Lisbon agenda255, intended to accommodate diversity, encouraging an exchange of best practices among Member States, to improve their

\footnotetext{
247 Van Dam, 2006, p.136-137.

248 Van Gerven, 2004 p.123.

249 Smits, 2008 p.1.

250 Brozaityte, 2009-2010 p.56.

251 Smits, 2006 p.20.

252 Brozaityte, 2009-2010, p.56.

253 Brozaityte, 2009-2010, p.56-57.

254 Larouche, 2008 p.7.

$255 \operatorname{COM}(2005) 24$.
} 
own national policies and achieve greater convergence towards the main EU goals. ${ }^{256}$ Such measure, used complementary together with minimum harmonization may provide for a movement towards a new form of governance in Europe, one that offers a fully decentralized approach, issuing guidelines and goals whilst striving to promote flexibility and openness, thereby moving away from binding and compulsory black and white letter law in form of paternalistic measures, but instead search for common denominators, that respect national preferences and traditions, that are more likely to overcome hostilities against the process of "Europeanization" in the area of product liability as well as private law generally. ${ }^{257}$

\section{Conclusion}

Undoubtedly one reason for the marginal success of Directive $85 / 374$ has been its timing: during the 1970's and 80's product liability jurisprudence had been in a developing stage, the Thalidomide disaster during the 1960's provided a notorious example of product injury which caught wide public attention and placed ideas of strict manufacturer liability at center stage of European thinking, and it was also during this time that news of a US product liability crisis first reached European actors and a political concern arose to promote consumer protection. However the end result has clearly been marked by the exhaustive political debate that led up to its adoption, wherein European key players seemed divided on the substantive content which such Directive should provide, leading to what is sometimes referred to as one of the high-water marks of political Euro-fudge.

The Directive sought to harmonize previously divergent national product liability laws, creating equal marketing conditions, in order to facilitate the internal market. However this paper has demonstrated that it has not reached this goal. Several obstacles remain; Optional provisions as well as numerous lacunae leave practically important aspects of a victim's claim entirely to national systems, and thereby provide for the continued existence of divergence as well as uncertainty. A further obstacle is that the Directive has been conceived in a way that allows Member state to maintain previously existing methods of recovery that, as has been highlighted, present the often more favorable choice for victims of defective products. The directive simply fails to improve the situation of consumers leaving it largely neglected in practice. The central concern of approximation of product liability laws seems lost, and the

256 European Council Presidency Conclusions, 23-24 March 2000.

257 Faure, 2003 p.8o. 
likelihood of Directive 85/374 functioning as the sole source of liability rather dim. Therefore the political success of the European model worldwide might be misleading as in reality one should have no illusions about its success in harmonizing the law in practice. Leaving such disparities aside, complete harmonisation will still be undermined by ambiguously defined key notions like defect that offer national courts the widest margin of interpretation possible. Hereby this paper has pointed towards diverging trends within Europe whereby national courts often seem to slip back into a negligence-type of analysis when determining defectiveness.

The Directive's apparent failure to provide for a "completely" harmonized system of product liability therefore warrants a critical review of the feasibility of such policy within the context of product liability, a question often disregarded in face of great enthusiasm for the challenge of harmonisation. This paper has argued that the economic need for full harmonisation does not exist, the underlying rationale to provide an equal level playing field seems fragmented, far too general and illusive. There is a general lack of empirical evidence which suggests that the internal market requires more than merely that product liability laws remain sufficiently narrow so as to not distort competition; this assumption seems rather to follow from legal politics than the actual needs of businesses and consumers.

This paper concluded that creating an identical product liability law across Europe is neither feasible nor desirable. This is not to say that the Directive has not been a valuable initiative or is in fact a "defective product" itself. The regime created has provided a common ground for a more harmonized development in the future. However this paper advocates that the current position held by the CJEU, keen to preserve the maximal nature of the instrument thereby creeping more competence within the area of product liability, at the expense of the national legislator, puts any prospects of further harmonisation on hold. Moreover it fails to recognize the complexities of product liability law, threatening the coherence of national private laws generally. Complete uniformity seems an unobtainable objective, at least for moment.

This paper has highlighted that there seems to be a need for reconsideration and finetuning of the interaction between the national and supranational level. This paper has advocated that a truly European product liability law in the future can only be achieved by starting at the national level, arguably better suited to deal with the needs of consumers and businesses within the area of private law. To this end it would be advisable to interpret the Directive as merely providing a common floor of rights, allowing member states to account for the needs of their system whilst striving towards more harmonisation. The EU hereby has the crucial role of facilitating and guiding such process. Within the context of the Product Liability Directive, emphasis should be placed on the drafting of a common 
standard of interpretation. The concepts provided by the Directive may be criticized for their vagueness, but such imprecision could be a blessing in disguise providing an opportunity for courts under the guidance of the EU to develop towards a harmonized interpretation of the instrument. This paper has emphasized the increasing relevance of comparative law, as guidance from the European Court of Justice remains scarce and cannot be guaranteed. The case $A v$ National Blood Authority nicely illustrates a possibility for and willingness of courts to undertake a cross-border exchange of experiences. The paper however also suggested several obstacles for lawyers trying to avail themselves of such tools.

European identity is defined by its diverse legal heritage; however the current version of the Directive seems to neglect these historical and cultural aspects that have led to a fast diversity among Member State laws; addressing these issues directly would provide for the creation of a new law that is formed through the contribution of a rich variation of national traditions, highlighting areas in which harmonisation is feasible. This in the long run will make it easier for Member states to integrate EU product liability rules into their national law that is less likely to be subject of diverging interpretation making maximum harmonisation a valuable option in the future. 


\section{Bibliography}

\section{Primary Sources:}

\section{Commission 1976}

- European Commission; More Protection for Consumers against defective products proposed. Commission Information Memo P-72/76, September 1976 [EU Commission Press Notice] COM (76) 372 final

\section{Commission 2000}

- Commission; Second Report from the Commission on the Application of Directive $85 / 374$ on the approximation of laws, regulations and administrative provisions of the Member States concerning liability for defective products. COM (2000) 893 final

\section{Commission 2006}

- Commission; Third Report on the application of Council Directive on the approximation of laws, regulations and administrative provisions of the Member States concerning liability for defective products. COM (2006) 496 final

\section{Commission 2011}

- European Commission; Fourth report on the application of Council Directive on the approximation of laws, regulations and administrative provisions of the Member States concerning liability for defective products. (COM (2011) 547 final)

Economic and Social Committee (ECOSOC) 1976

- Economic and Social Committee (ECOSOC); Report on the Proposal for a Council Directive on Liability for defective products. COM (1976) 372 final

Economic and Social Committee (ECOSOC) 1979

- Economic and Social Committee (ECOSOC); Opinion on the proposal for a Council Directive relating to the approximation of the laws, regulations and administrative provisions of the Member States concerning liability for defective products. OJ C114/05 (1979).

Legal Affairs Committee 1979-1980

- Report of the Legal Affairs Committee [1979-1980] European Parliament Document COM No.71 


\section{Secondary Sources:}

\section{Andenas, Bell \& Fairgrieve 2002}

- Andenas, Bell, Fairgrieve; The Emergence of a Common European Law in the Area of Tort law: the EU Contribution. Published in W. van Gerven; Comparative Law in a regionally integrated Europe. In Comparative Law in the $21^{\text {st }}$ century WG Hart Legal Workshop Series, London: Kluwer Academic Publishers, 2002, 155 Chapter 6

\section{Allee 1984}

- John S. Allee; Product Liability. ALM Properties, Inc., Law Journal Press, 1984 available via Google books http://books.google.de/books?id=Kc4BIWh_BoC\&pg=PR2\&dq=John+S.+Allee;+Product+ Liability.+ALM+Properties,+Inc., +Law+Journal+Press,+1984\&hl=de\&sa=X\&ei=ByHjUf6e KMOswb4i4G4DA\&ved=oCDEQ6AEwAA\#v=onepage\& $q=J$ ohn\%2OS.\%2OAllee\%3B\%2O Product\%2oLiability.\%2OALM\%2OProperties\%2C\%2OInc.\%2C\%2OLaw\%2OJournal\%2O Press\%2C\%201984\&f=false

\section{Bartl 1989}

- H. Bartl; Produkthaftung nach neuem EG-Recht: ProdHaftG. Kommentar zum deutschen Produkthaftungsgesetz. Verlag Moderne Industrie, 1989

\section{Baum 1988}

- Lothar W. Baum; Forum Shopping in Product Liability Actions: A Comparison Between the United States, France and Germany. [Thesis] University of Georgia School of Law, 1988

\section{Bernstein 1992}

- Anita Bernstein; Looking at Europe for the Difference Between Strict and Fault-Based Liability. Journal of Products Liability Volume 14. 207, 1992

Bianco 2002

- Nicolo Cornelius Bianco; Modern Trends in Product liability. [Dissertation] University of South Africa, 2002

\section{Boger 1984}

- William Boger; The Harmonisation of European Products Liability Law. Fordham International Journal Vol.7 Issue 1 Article 1, 1984

\section{Brozaityte 2009-2010}

- Edita Brozaityte; How is the shift from minimum to maximum harmonisation reflected in the Proposal for the Directive on Consumer Rights and is it Legally feasible and desirable? [Master Thesis] Tilburg University, 2009-2010 


\section{Buxbaum, Hertig, Hirsch \& Hopt 1996}

- Richard M. Buxbaum, G. Hertig, A. Hirsch \& K.J. Hopt (eds.); European Economic and Business law: Legal and Economic Analysis on Integration and Harmonisation. De Gruyter \& Co., 1996

Cavaliere 2001

- Alberto Cavaliere; The Economic Impact of Product Liability and Product Safety Regulations in the European Union. Quaderni del Dipartimento di Economia Pubblica E Territoriale - Università di Pavia n.4/2001, 2001

\section{Corr 1990}

- Marianne Corr; Problems with the EC Approach to Harmonisation of Product Liability Law. Case Western Reserve Journal of International Law, Spring/Summer 90, Vol.22 Issue 2/3, pp. 235-244, 1990

\section{Eger \& Schäfer 2012}

- Thomas Eger \& Hans-Bernd Schäfer; Research Handbook on the Economics of European Union Law. Edward Elgar Publishing Limited, 2012 available via Google books http:// books.google.de/books?id=sKSSObMSih4C\&printsec=frontcover\&dq=Thomas+Eger+\%26+ HansBernd+Schäfer;+Research+Handbook+on+the+Economics+of+European+Union+Law. + Edward+Elgar+Publishing + Limited, $+2012 \& h l=d e \& s a=X \& e i=T Z X j U c y \_G c 3 E t A a d i o C I A Q \& v$ ed $=O C D E Q 6 A E W A A \# v=$ onepage $\& q=$ externalities $\& f=$ false

Fairgrieve 2005

- Duncan Fairgrieve; Product Liability in Comparative Perspective. Cambridge University Press 2005

\section{Fairgrieve 2005}

- Duncan Fairgrieve; L'exception française? The French law of product liability. Published in Duncan Fairgrieve; Product liability in Comparative Perspective. Cambridge University Press, 2005

Fairgrieve \& Howells 2007

- Duncan Fairgrieve \& Geraint Howells; Rethinking Product Liability: A Missing Element in the European Commission's Third Review of the European Product Liability Directive (Legislation and Reports). The Modern Law Review Limited Journal Compilation, pp.962-978, 2007

Fairgrieve \& Howells 2007

- Duncan Fairgrieve \& Geraint Howells; State of art of European Product Liability. Published in Australian Product Liability Reporter Vol.18 Issue 2, 2007 
Faure 2000

- Michael G. Faure; Product Liability and Product Safety in Europe: Harmonisation or Differentiation? Kyklos: International Review for Social Sciences Vol.5 pp.467-508, 2000 Faure 2003

- Michael G. Faure; How Law and Economics may contribute to the Harmonisation of Tort Law in Europe. Published in R. Zimmerman (Ed.); Grunstrukturen des Europäischen Deliktsrechts pp.31-82, Baden-Baden: Nomos, 2003

Flear, Farell, Hervey \& Murphy 2013

- Mark L Flear, Anne-Maree Farrell, Tamara K. Hervey \& Thérèse Murphy; European Law and Health Technologies. Oxford University Press, 2013

Folsom, Lake \& Nanda 1996

- Ralph H. Folsom \& Ralph B. Lake \& Ved P. Nanda; European Union Law After Maastricht:A Practical Guide for Lawyers Outside the Common Market. Kluwer Law international, 1996 Geer 1992

- Thomas V. Greer; Product Liability in the European Community: The Legislative History. Journal of Consumer Affairs Vol.26 Issue 1, 1992

\section{Harttkamp \& Hondius 2004}

- Arthur S. Hartkamp \& Ewoud Herman Hondius; Towards a European Civil Code $3^{\text {rd }}$ edition. Kluwer Law International, 2004

Hoftstede 2001

- G. Hoftstede; Cultures Consequences $2^{\text {nd }}$ edition. London, Sage, 2001

Howells, 2005 (1)

- Geraint Howells; Product Liability - A History of Harmonisation. Published in Duncan Fairgrieve; Product Liability in Comparative Prospective. Cambridge University Press, 2005 Howells, 2005 (2)

- Geraint Howells; Defect in English Law: Lessons for harmonisation of European Product Liability. Published in Duncan Fairgrieve; Product Liability in Comparative Perspective. Cambridge University Press pp.138-152, 2005

Howells 2006

- Geraint G. Howells; The Rise of European Consumer Law - Whither National Consumer Law? Sydney Law Review Vol.28 Issue 63, 2006

Howells 2008

- Geraint Howells; Is European Product Liability Harmonized? Tort and Insurance Law Vol.23, 2008 


\section{Huber \& Litan 1991}

- Peter W. Huber \& Robert E. Litan; The Liability Maze: The Impact of Liability Law on Safety and Innovation. Brookings Institution, Washington, 1991

Hunter, Bergkamp Hunton \& Williams 2001

- Rod Hunter \& Lucas Bergkamp Hunton \& Williams; Should Europe's Liability Regime Be Expended? Comments on the European Commission's Green Paper on Product Liability. Product Safety \& Liability Reporter Vol.29, No.17 pp.403-417, 2001 Bureau of National Affairs. Inc., Washington, D.C.

Hulsenbek \& Campbell 1989

- R. Hulsenbek \& D. Campbell; Product Liability: Prevention, Practice and Process in Europe and the United States. Kluwer Law International, 1989

Joerges 2004

- Christian Joerges; The Challenges of Europeanization in the Realm of Private Law: A Plea for a New Legal Discipline. EUI Working Paper LAW No.2004/12 European University Institute, Florence Department of Law 2004

Kramer \& van Rhee 2012

- X.E. Kramer \& C.H. van Rhee; Civil Litigation in a Globalizing World. Asser Press, 2012

Koch 2010

- Bernhard A. Koch; Damage Caused by Genetically Modified Organisms: Comparative Survey of Redress options for Harm to Persons, Property or the Environment. De Gruyter $\mathrm{GmbH} \&$ Co. KG, Berlin 2010. Available via Goggle books http://books.google.de/book $s ? i d=Y X M L 8 F Z d Y v 8 C \& p g=P A 185 \& d q=J .+$ Calais + Auloy; +'Menace+européenne $\& h l=d e \& s a$ $=X \& e i=T Y P j U b i U C 4 e 10 O G C g b A O \& v e d=0 C D g Q 6 A E W A Q \# v=$ onepage $\& q=J . \% 20$ Calais\%20Auloy\%3B\%20'Menace\%20européenne\&f=false

Korzec 1997

- Rebecca Korzec; Dashing Consumer Hopes: Strict Products Liability and the Demise of the Consumer Expectations Test. Boston College International \& Comparative Law Review Vol. XX, No.2, 1997

Larouche 2008

- Pierre Larouche;'Legally Relevant Damage' and a priori limits to non-contractual liability in the DCFR. [TILEC Discussion Paper] December 2008 (DP 2008-045)

Legrand 1997

- Pierre Legrand; The impossibility of Legal transplants. Maastricht Journal of European and Comparative Law Vol.4 1997 


\section{Lenze 2005}

- Stefan Lenze; German Product Liability Law; Between European Directives, American Restatements and common sense. Published in Duncan Fairgrieve; Product Liability in Comparative Perspective. Cambridge University Press, 2005

Linger 1990-1991

- Lori M. Linger; The Products Liability Directive: A Mandatory Development Risks Defense. Fordham International Law Journal Volume 14 Issue 2 Art.6 pp.478-509, 1990-1991 Loos 2006

- Marco B.M. Loos; The Influence of European consumer law on general contract law and the need for spontaneous harmonisation: On the disturbance and reconstruction of the coherence of national contract law and consumer law under the influence of European law. Centre for the Study of European Contract Law Working Paper Series No. 2006/02, 2006 p.8

Lovell 2003

- Lovell; Product Liability in the European Union: A report for the European Commission (European Commission Study). February 2003 Markt/2001/11/D

\section{Mak 2009}

- Vanessa Mak; The Degree of Harmonisation in the Proposed Consumer Rights Directive: A Review in the Light of Liability for Products. Tilburg Institute of Comparative and Transnational Law (TICOM) Working Paper No. 2009/03, published in Geraint Howells and Reiner Schulze (eds.); Modernizing and Harmonizing Consumer Contract Law. Sellier, München March pp.307-24, 2009

\section{Mottur 1993-1994}

- Alfred E. Mottur; The European Product Liability Directive: A Comparison with U.S. Law. An Analysis of its Impact on Trade and a Recommendation for Reform so as to accomplish harmonisation and consumer protection. Law \& Policy in International Business Vol.25, 1993-1994

Nilles 1985

- Kathleen M. Nilles; Defining the Limits of Liability: A Legal and Political Analysis of the European Community Products Liability Directive. Virginia Journal of International Law Vol.25, 1985

\section{Orban 1978}

- Frank A. Orban, III; Product liability: A Comparative Legal Restatement - Foreign National Law astatine the EEC Directive. Georgia Journal of International and Comparative Law Vol.8 Issue 2 pp.342-408, 1978 


\section{Paolisa 2004}

- Nebbia Paolisa; Internal market and the harmonisation of European Contract law. Published in Tridimas Takis; Nebbia Paolisa; European Union Law for the twenty-first century: rethinking the new legal order (Vol. 2 International market and free movement community policies). Oxford University Press, 2004

Rajneri 2005

- Eleonora Rajneri; Interaction Between the European Directive on Product Liability and the former liability regime in Italy. Published in Duncan Fairgrieve; Product Liability In Comparative Perspective. Cambridge University Press, 2005

\section{Reimann 2003}

- Matthias Reimann; Product Liability in a Global Context: the Hollow Victory of the European Model. European Review of Private Law 2-2003 [128-154] Kluwer International 2003

Schmid 2003

- Christoph U. Schmid; Co-ordination problems between European and national private law: a Scenario to be avoided in the Europeanization of Tenancy Law. [Background Paper] European Private Law Forum EUI Florence, 2003 available via http://www.iue.it Schulze 2011

- Reiner Schulze (eds.); Compensation of Private Losses: The Evolution of Torts in European Business Law. Sellier European Law Publisher GmbH, 2011

Shuibhne 2006

- Niamh Nic Shuibhne; Regulating the Internal Market. Edward Elgar Publishing Limited, 2006

Smits 2006

- Jan M. Smits; European Private Law: A Plea for a Spontaneous Legal Order. Maastricht Working Papers, Faculty of Law, 2006

Smits 2008

- Jan M. Smits: Mixed Jurisdictions: Lessons for European Harmonisation? Electronic Journal of Comparative law Vol.12 Issue I, 2008

Stapleton 1993

- Jane Stapleton; A Personal Evaluation of the Implementation of the EEC Directive (85/374/EEC) on Products Liability. 1 Torts Law Journal 90 (1993)

\section{Stapleton 1994}

- Jane Stapleton; Product Liability. Butterworth Legal Publishers, 1994

Stapleton 1999

- Jane Stapleton; Product Liability in the United Kingdom: The Myths of Reform. Texas International Law Journal Vol.34, 1999 


\section{Stapleton 2001-2002}

- Jane Stapleton; Bugs in Angelo-American Products Liability. South Carolina Law Review Vol.53 Issue 1225 pp.1226-1259, 2001-2002

Taylor 2005

- Simon Taylor; Harmonisation or Divergence? A comparison of French and English product liability rules. Published in Duncan Fairgrieve; Product Liability in Comparative Perspective. Cambridge University Press, 2005

Thieffry 1989

- Patrick Thieffry; Strict Product Liability in the EEC: Implementation, Practice and Impact on U.S. Manufacturers of Directive 85/374. Tort \& Institutions Law Journal Volume 25, 1989

Van Dam 2005

- Cees van Dam, Dutch Case Law on the EU Product Liability Directive. Published in Duncan Fairgrieve; Product Liability in Comparative Perspective. Cambridge University Press, 2005

\section{Van Dam 2006}

- Cees van Dam; European Tort Law. Oxford University Press, 2006

\section{Van Dam 2007}

- Cees van Dam; European Tort Law and the Many Cultures of Europe. Published in Thomas Whilhelmsson (ed.); Private Law and the Cultures of Europe. Chapter 4 pp.53-76 Kluwer Law International BV, 2007

\section{Van den Berg 1998}

- Roger Van den Bergh; Subsidiarity as an Economic Demarcation Principle and the Emergence of European Private Law. Maastricht Journal of European and Comparative Law Vol.5 pp.129-152, 1998

\section{Van den Berg 1999}

- Roger Van den Berg; Economics in a legal straightjacket: the difficult reception of economic analysis in European Law. Paper Presented at the Workshop Empirical Research and Legal Realism. Setting the Agenda, Haifa, June 6-9 1999

\section{Van Gerven 2004}

- Walter van Gerven; European Court of Justice as a Means of Unification of Private Law? Published in A. Hartkamp e.a. (Eds.); Towards a European Civil Code, $3^{\text {nd }}$ ed. Kluwer Law International, 2004

\section{Van Wassenaer \& Van Catwijk 1986}

- Van Wassenaer \& A.J. Otto Van Catwijk; Productaansprakelijkheid in Serie Praktijkhandleidingen. Zwolle: Tjeenl Willink, 1986 
Van Wees \& Brookhuis 2005

- Kiliaan van Wees and Karel Brookhuis; Product liability for ADAS; Legal and Human factors perspectives. Delft University of technology, Policy and Management, EJTIR, Vol.5, no.4, pp.357-372, 2005

Wilhelmsson 2007

- Thomas Wilhelmsson (ed.); Private Law and the Cultures of Europe. Kluwer Law International, 2007

Williamson 2003

- Shanti Williamson; Compensation for Infected Blood Products: A and others v National Blood Authority and Another. Electronic Journal of Comparative Law Vol.7 Issue 5, ISSN 1205-8629, 2003

\section{Internet Sources:}

British Institute of International and Comparative Law

- $\quad h t t p: / / w w w . b i i c l . o r g / p l f /$

European Council Presidency Conclusions, 23-24 March, 2000

- http://www.ec.europa.eu/index_en.htm

Institute for European Tort Law (ETL)

- http://ectil.org/etl/Einfuhrung.aspx

Science in Society

- http://scienceinsociety.northwestern.edu/content/articles/2009/research-digest/ thalidomide/title-tba

TheFreeDictionary.com

- http://legal-dictionary.thefreedictionary.com/Product+Liability 